\title{
SEQUENCES OF THE TRANSYLVANIAN LIMESFORSCHUNG. ISTVÁN FERENCZI AND THE LIMITES RESEARCH IN DACIA PorolisSENSIS
}

HORAȚIU COCIȘ

\section{REZUMAT: ISTVÁN FERENCZI ŞI CERCETAREA FRONTIEREI ROMANE DIN TRANSILVANIA}

Articolul de față se concentrează pe activitatea arheologului maghiar István Ferenczi (1921-2000) în sfera cercetării frontierelor romane. $\mathrm{Cu}$ ocazia celei de-a o suta aniversări a nașterii sale, considerăm mai mult decât necesară realizarea unei treceri în revistă a muncii sale enorme de pionerat în cercetarea fortificatiilor minore (turnuri de supraveghere, fortificații mijlocii de tip burgus) și liniare, frontaliere, împreună cu o abordare a perspectivelor sale teoretice despre cum funcționa frontiera Daciei nordice. Structura studiului va urma câteva aspecte cheie prin care dorim să prezentăm în manieră sintentică activitatea contextualizată a lui Ferenczi în domeniul menționat mai sus. După o scurtă introducere care va conține câteva note biografice, vom discuta pe rând probleme care țin de cercetarea sa de teren în diferite zone ale Daciei Porolissensis, de cele (câteva) cercetări arheologice precum și despre interpretările generale privind funcționalitatea frontierei romane.

\section{ABSTRACT:}

The present article focuses on the activity of the Hungarian archaeologist István Ferenczi (1921-2000) in the field of Roman frontier studies. On the occasion of his $100^{\text {th }}$ birthday, we consider it more than necessary to review his enormous pioneering research on the minor (watchtowers, fortlets) and linear frontier fortifications, together with an approach regarding his theoretical outlooks on how the frontier of the northern Dacia worked. The structure of the study will follow several key aspects through which we want to present Ferenczi's research and contextualized activity synthetically, as mentioned. After a brief introduction that will contain a few biographic notes, we will discuss, by turn, issues regarding his field surveys in various frontier areas of Dacia Porolissensis, his (few) archaeological excavations, his theoretical background, and his general interpretations of the functionality of the Roman frontier.

CUVINTE CHEIE: Ferenczi István, frontiera romană, Dacia Porolissensis, cercetări de teren, teorie arheologică.

KEYWORDS: Ferenczi István, Roman frontier, Dacia Porolissensis, field survey, archaeological theory.

\section{Who was István Ferenczi? Short biographical notes}

Born on the April 151921 in Cluj / Kolozsvár, István Ferenczi was the first son of Ferenczi Sándor, a Hungarian - born scholar formed within the archaeological school founded by Béla Pósta. Participating in his father's archaeological excavation from the early age of three ${ }^{1}$, Ferenczi revolved around this research activity type. His upper secondary education was accomplished at the Reformed College of Cluj / Kolozsvári Református Kollégium, where he studied, among other subjects, history and linguistics with S. Biró and G. Finta. Later, in 1940, he began his studies in history and geography at the Ferenc Jósepsh University of Cluj under the supervision of several renowned Hungarian archaeologists such as G. László or I. Méri. ${ }^{2}$

Also, during this period, namely in 1941, he published his first study regarding the north-western area of the frontier of Dacia Porolissensis, following the earlier research of Károly Torma and Árpád Buday ${ }^{3}$ (the study was published on the occasion of the anniversary of 80 years since the beginnings of Torma's research on limes Dacicus ${ }^{4}$ ),

Vincze 2001, 347. For other evocations see especially Dénes 2000, 18-21; Ambrus 2000, 2; Vincze 2000, 326-329; Vincze 2000a, 27-29; Bârsu, C. 2000. Clujeni ai secolului 20: dicţionar esenţial. Cluj-Napoca: Casa Cărţii de Ştiinţă, 116.

2 Vincze 2001, 347.

3 Cociș 2016, 41-44.

4 Ferenczi 1941, 189. 
indicating from now on one of his central direction of archaeological research: the frontiers of Roman Dacia. Unfortunately, his early studies and research were brutally interrupted by the Second World War, when he was enrolled and sent on Germany and Denmark's frontlines in 1943, subsequently captured by the English Army and imprisoned for 17 months. ${ }^{5}$ He finished the studies after the end of the war, being appointed as a teacher in 1947. Later, in 1948, Ferenczi was appointed as an assistant professor at the Department of Archaeology led by G. László and, in 1952, a lecturer. At the same time, he was hired as a researcher at the History Institute of the People's Republic of Romania $(1949-1956)^{6}$.

With the founding of the National History Museum of Transylvania in 1962, Ferenczi was transferred to the newly created structure, being head of the Prehistory Department, Roman and Dacian History and Prefeudal period ${ }^{7}$. Even if he officially retired in 1982, his activity in the field of history and archaeology remained constant at a high level. He continued the field surveys in Transylvania as well as the detailed data dissemination. After 1989, he continued his teaching career within the Babeș-Bolyai University of Cluj-Napoca, Hyperion University of Bucharest (Sfântu Gheorghe branch), and

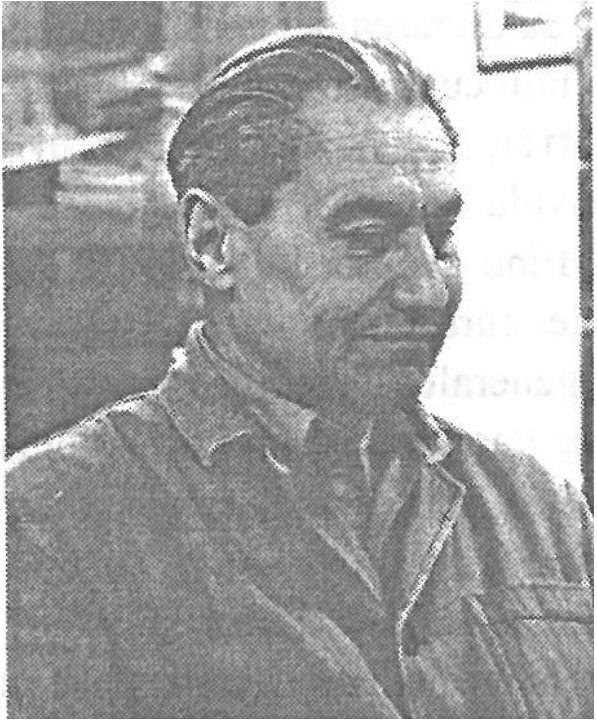

Fig. 1. István Ferenczi (1921-2000). After Vincze 2001, 347. Janus Pannonius University of Pécs ${ }^{8}$. After a long but difficult career, the same university of Pécs awarded Ferenczi the distinction of doctor honoris causa in $1996^{9}$.

The fields of study that Ferenczi addressed during his career were numerous, producing over 300 studies concerning the Prehistory, pre-Roman Dacia, the Province, the migration period and the early Middle Ages, and other papers regarding the museums and the museography of Transylvania. ${ }^{10}$ Unfortunately, his outstanding work and results have not been fully capitalized on by the generations that followed, with few exceptions. Therefore, in the following pages, we intend to refresh and closely review his activity and results in the field of the Roman frontier study from Transylvania.

\section{The context. Limes Dacicus, Torma's legacy and the Roman frontier studies in the second half of the $19^{\text {th }}$ - early $20^{\text {th }}$ century.}

To integrate Ferenczi's work on the Roman frontier from Transylvania, we must first analyze briefly the research carried out by the early archaeologists of the Belle Époque. The evolution of the archaeological research in Transylvania after 1918 is organically related to the previous period ${ }^{11}$ when the Hungarian or German-born scholars took the first steps to identify and research archaeological sites belonging to the Roman limites ${ }^{12}$. The first written accounts on the Roman frontier sites are much older than the year mentioned above ${ }^{13}$. Except for some unexplored areas, Ferenczi's field surveys were based on the previous work accomplished by Károly Torma, Árpád Buday or Téglás Gábor.

As he rightly pointed out, the Roman frontiers research in Transylvania began by chance, namely due to the misreading of a famous inscription ${ }^{14}$. The inscription in question ${ }^{15}$ was discovered within the auxiliary fort at Samvm / Cășeiu (Cluj County), subsequently moved at the Haller Castle from Coplean (Cluj County), discovered

\footnotetext{
Vincze 2001, 347.

Vincze 2001, 348.

Vincze 2001, 348.

Vincze 2001, 348.

See in this direction the laudationes from 1996 in László 1996, 7-14 and Tóth 1996, 15-16;

10 The (almost) complete bibliography of I. Ferenczi (on-line version) in: https://www.sulinet.hu/oroksegtar/data/kulhoni magyarsag/2010/ro/csiki_2009_regeszet/pages/001_Ferenczi_Istvan.htm. The compilation contains all the four bibliographic lists available up to now.

11 Cociş 2018, 117.

12 See especially Gudea 1997, 7-18, Marcu, Cupcea 2013, 569-573, Cociș 2016, 41-46.

13 See for example the descriptive repertoire of K. G. v. Windisch from 1790 (Windisch 1790, 439-440) or the older site descriptions (in Latin) of the catholic prelate Iosif Vaida, dated 12 November 1859 (Ardevan 1977, 135-137).

14 Ferenczi 1971, 613; Cociș 2016, 41.

15 CIL III, 827.
} 
and interpreted by Torma ${ }^{16}$. The inscription was raised by an aedilis coloniae Napocae and beneficiarius consularis named Valerius Valentinus for the goddess Nemesis ${ }^{17}$; the inscription is also the first attestation of vicus Samvm, the settlement on the banks of the river Someș ${ }^{18}$. Torma's misread the part ...subsi[g](navit) Samum cum reg(ione) (tr)ans vall(um).. ${ }^{19}$ (later corrected and reread by A. v. Domaszewski ${ }^{20}$ ).

However, being confident in the existence of a certain regio transvallum, Torma started in 1862 his first field surveys on the Meseș Mountains in order to discover the traces of the vallum - the traces of the Roman frontier - the later limes Dacicus ${ }^{21}$ as he named the limes stretch from Bologa auxiliary fort to Porolissum, an year later, in $1863^{22}$. His repeated expeditions over the years led to the first identifications of the physical elements of the frontier, most of them located within the frame of the north-western areas and only a few meters north of Someș River. As N. Gudea once underlined, the first archaeological discoveries of Torma in the frontier area at Bologa - Poieni were a complete surprise ${ }^{23}$. After a survey that could be nevertheless called a blind survey, he managed to identify in the north-western confines no less than 25 watchtowers, three fortlets and two linear fortifications ${ }^{24}$ and other (at least) two watchtowers near the auxiliary fort and vicus at Ilișua - Arcobara ${ }^{25}$. The field surveys were accompanied by accurate descriptions of the location and state of preservation, ground plans and altimetric profiles ${ }^{26}$.

Besides this tremendous work, Torma conceived two interpretative directions, strongly contradicted by his colleagues. The first of them established that the ruins found within the Meses Mountains were of Roman origin, and second, he postulated the existence of a continuous palisade that sealed the frontier of Dacia (based on the fact that he identified an earth vallum near Poieni village - Cluj County and another one near Brebi village Sălaj County). The possibility of an anthropic, continuous linear fortification built after the well known British or Germanic mode ${ }^{27}$ was heavily criticized immediately by O. Tivadar in $1875^{28}$. A year later, F. F. Rómer also contested the theory of continuous palisade ${ }^{29}$. After his $A$ Limes Dacicus felsö része, the foundation of the studies regarding the Roman frontier from Dacia Porolissensis, the Roman nature of the finds is no longer questioned and criticized, the arguments being even more reliable. This time, Torma's statements are much more cautious and barely visible in the economy of the study regarding the continuous palisade ${ }^{30}$. As expected, the criticism came this time from German scholars, namely from A. v. Domaszewski and Th. Mommsen, both of them neglecting the finds ${ }^{6}$ antique characters, the reality of a regio transvallum, and, in the end, the whole concept of limes Dacicus ${ }^{31}$. However, Domaszewski believed in a continuous barrier of Talspereen-type on the Meseș Mountains, an idea that will be mechanically used (without field surveys or any other direct proofs) by some prestigious scholars from the $1^{\text {st }}$ half of the $20^{\text {th }}$ century ${ }^{32}$.

As respects the northern sector, mainly the stretch from Cășeiu/Samvm to Ilișua/Arcobara, we must say that it received little attention from the Transylvanian Limesforschung scholars, the systematic research being carried for the first time by Ferenczi. Nevertheless, Torma found two watchtowers near the auxiliary fort at Arcobara (of which one was almost fully excavated ${ }^{33}$ ), not enunciating any hypothesis regarding the functionality of the chain line located north of River Someș. To resume, we underscore the fact that Torma's work as a whole became in time a must-read for every scholar who wants to start research on the limites of Dacia Porolissensis.

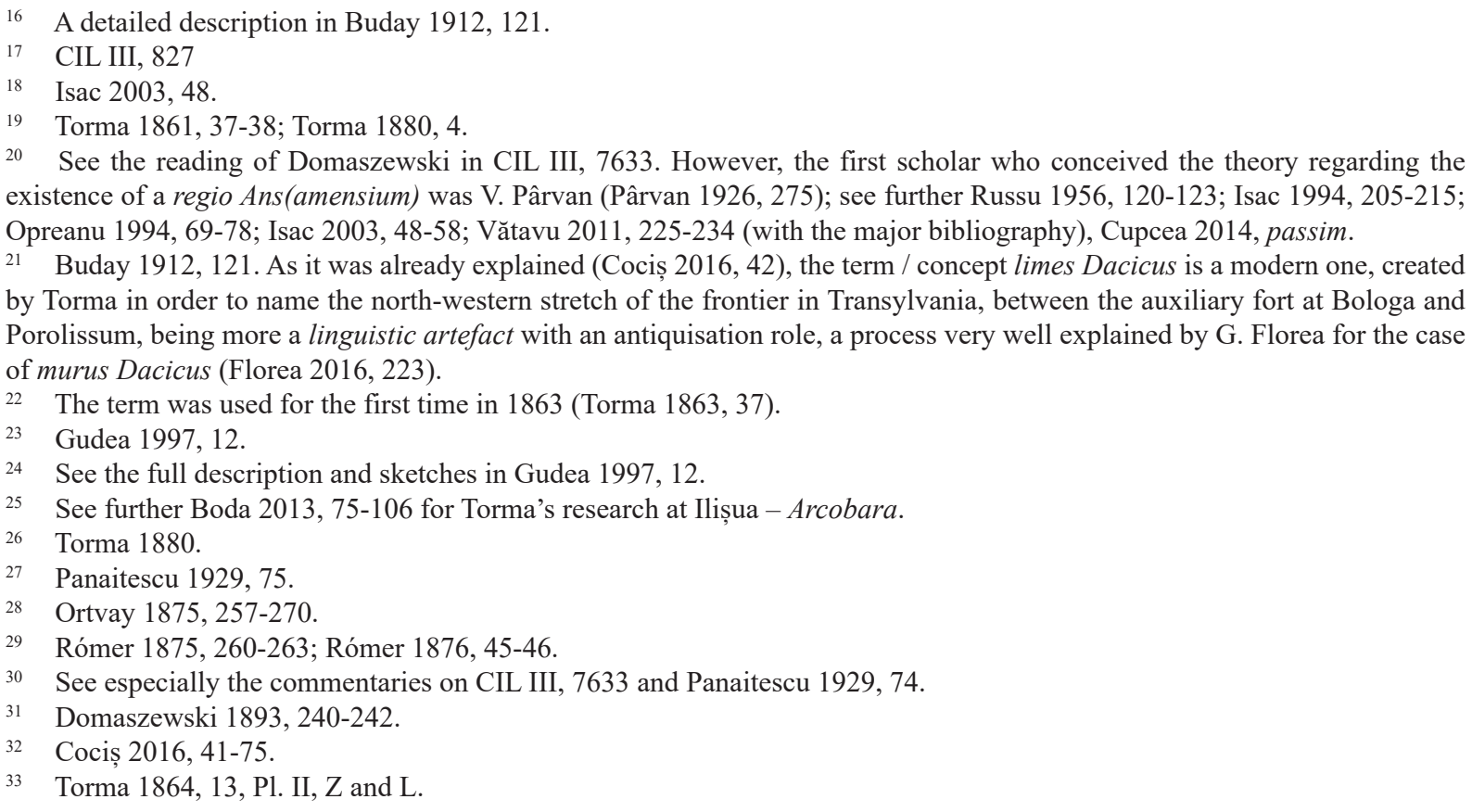




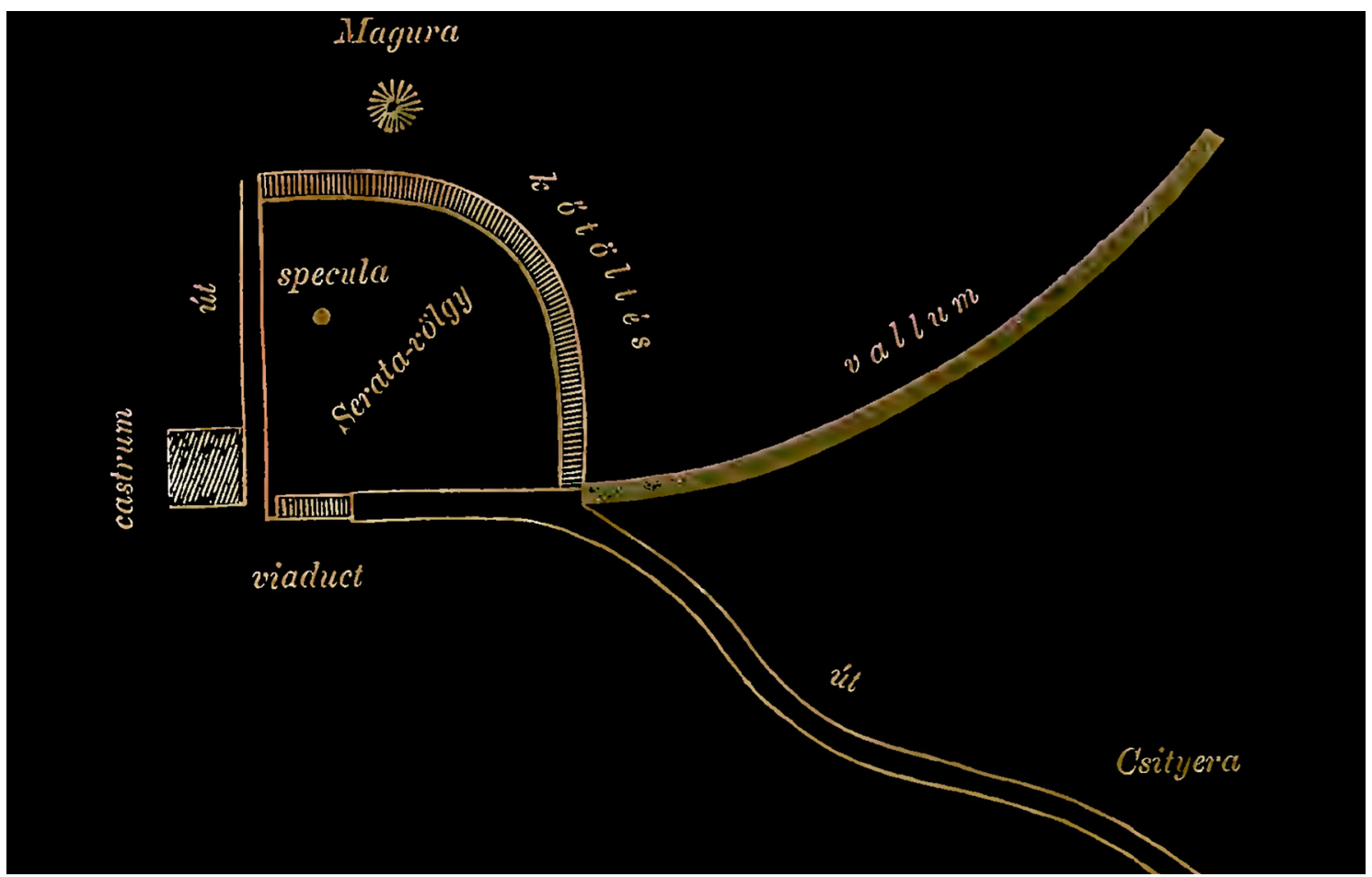

Fig. 2. Porolissum and its defensive elements as seen by K. Torma; reverse colours (after Torma 1880, 82, Fig. 6).

After Torma's departure at Porto d'Anzio in 1887 and his death, which occurred in 1897, the general interest for this subject dropped significantly until a new generation of scholars reopened the dossier of limes Dacicus. Several years later, in the first decades of the $20^{\text {th }}$ century, the research history recorded three names related to the topic: Gábor Finály, Gábor Téglás, and Árpád Buday. G. Finály followed Torma's account on Poguior Hill ${ }^{34}$, a central element of the frontier crossing point of Poarta Meseșană pass ${ }^{35}$. Even if he excavated the stone circular ruins of the watchtower and the Dacian turf and timber enclosures, he found Roman building material, potsherds, jewellery pieces, and metal artefacts, completely denying the chronology of these finds, neglecting Torma's (correct) accounts automatically ${ }^{36}$.

Starting from 1906 onward, G. Téglás began his research on the north-western frontier of Dacia Porolissensis. In the same year, he made a documentary trip on the $O R L^{37}$. The research visit was finalized by publishing a study on the liner frontier systems of Germania and Raetia, including a series of personal comments on the modus operandi of this particular linear framework ${ }^{38}$. In the following year, he publishes a brand new study where he automatically imported the spatial and functional patterns of the $O R L$, strongly supporting the existence of the same system in Dacia Porolissensis ${ }^{39}$. Thus, he adopted a different physical reality mechanically, postulating a theory that suggests a continuous palisade within the Meseș Mountains area without any scientific basis. More than that, he denied the realities encountered in his field surveys, subsequently attracting fervent criticism from I. Ferenczi ${ }^{40}$.

The correspondence carried by Téglás ${ }^{41}$ in order to obtain financial support from the local authorities and the Hungarian Academy of Sciences between 1906 - 1907 encountered several difficulties. In the end, the funding applications were rejected for no apparent, coherent reason. ${ }^{42}$ Despite this lack of funding, it is more than certain that Téglás carried out archaeological research founded by other (yet) unknown sources; unfortunately, we cannot say to which extent he researched the north-western frontier (and especially where). In 1912, Á. Buday noted that he received a research report written by Téglás ${ }^{43}$ in which it is mentioned that he undertook field research in

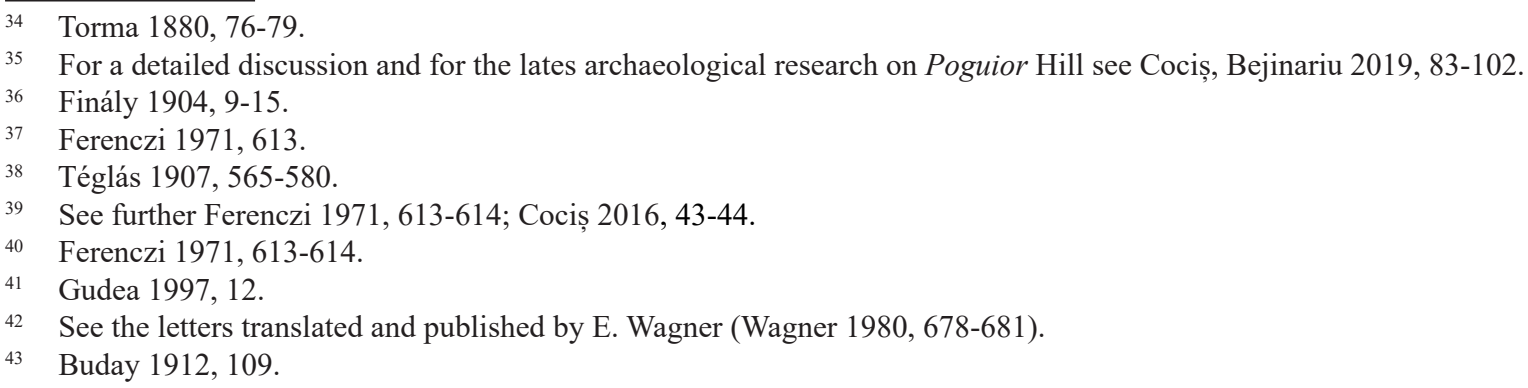


the northern and north-eastern areas of the Roman Province (?) ${ }^{44}$. Téglás was harshly criticized by his colleagues and by the next generation of scholars due to the outdated research methods ${ }^{45}$. His theories were considered pure fantasy, lacking the scientific rigour of the German school, whose influence marked him in full ${ }^{46}$.

Like his colleague before, Á. Buday undertook a research trip on the German frontier before the actual field research in Dacia Porolissensis, acquainting with the linear system and the general organization of this particular frontier type ${ }^{47}$. He published a detailed study on the ORL at the end of the visit, but much more detailed than his predecessor, using sketches, artistic drawings, and even site photos ${ }^{48}$. Returning to Transylvania, Buday began, particularly following Torma's descriptions, the field surveys on the north-western sector of limes Dacicus, from Bologa - Poieni (Cluj County) area up to Porolissum, his records being of high importance. He used the same method applied on the ORL, a large scale survey accompanied by detailed descriptions and site photos (for the first time on the frontier of Dacia Porolissensis $)^{49}$. He also made a series of altimetric profiles of the encountered ruins (especially watchtowers and fortlets but also several linear fortifications). ${ }^{50}$ Besides a series of new finds and accurate descriptions, he made the first topographical map of the Meseș Mountains containing the main toponymy of the Roman frontier sites ${ }^{51}$.

Even though his field record methods are marked by visible technical progress, Buday adopted the classical theory that postulates a continuous linear fortification on the course of the Meseș Mountains, being criticized in turn, mainly by I. Ferenczi ${ }^{52}$. This automatic mechanism is similar to the one used by his predecessor, extrapolating the archaeological realities attested on the frontiers of Germania and Raetia in the north-western area of Dacia Porolissensis, falling in the same interpretative trap. We believe that this theory's climax is reached with the statements of Ernst Fabricius. He (utterly undocumented) emphasized the idea of a continuous turf and timber palisade that connected Porolissum with the Danube ${ }^{53}$ a concept primarily inspired by Mommsen's double frontier theory ${ }^{54}$..Later, Giovanni Forni adapted to some extent Fabricius's theory, postulating a continuous hermetically sealed border ${ }^{55}$.

Starting with 1909, Iulian Marțian began to show interest in the

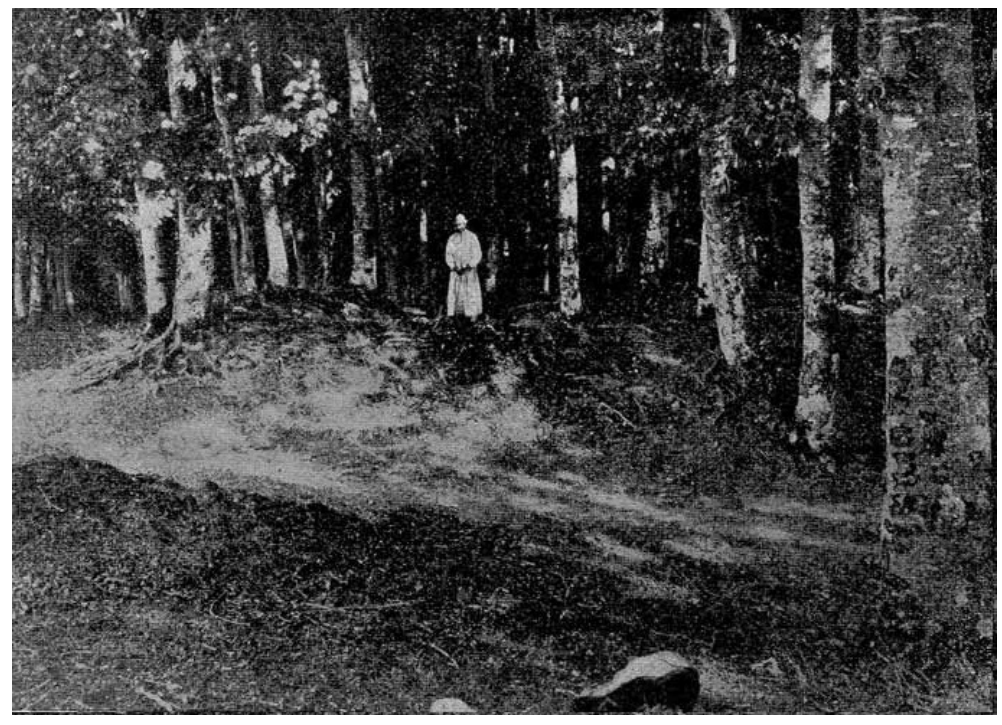

Fig. 3. The stone watchtower at Vârful Teghișului (Sălaj County) in 1912 (after Buday 1912, 114, Fig. 10). Transylvania antiquities in general and the Roman frontier of Dacia in particular ${ }^{56}$. In his study from $1920^{57}$ he described (with the necessary exaggerations) the frontier system at Porolissum, creating a series of general ground plans ${ }^{58}$. I. Marțian generally describes several linear fortifications, watchtowers, and fortlets ${ }^{59}$. After these records, he interpreted the minor and linear structures

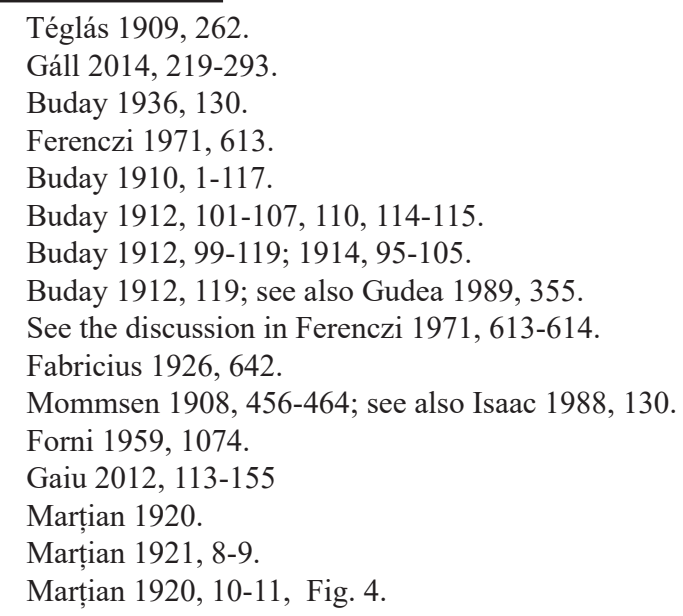


as continuing from Porolissum up to Maramureș County (Lăpuș area) ${ }^{60}$. The subsequent explanations about the frontier system of Dacia Porolissensis being an absolute fiction.

At the end of the third decade of the $20^{\text {th }}$ century, a shift of research interests is visible, from the north-western area of Dacia Porolissensis ${ }^{61}$ to the northern one, especially between the auxiliary forts at Samum and Arcobara. Except for the later research carried out by I. Ferenczi, the understanding process of these particular segments does not exceed the theoretical level. Emil Panaitescu made the first attempt. During the archaeological excavations carried out at Samum auxiliary fort, he postulated a Roman frontier existence on the course of the Someș river, at a distance of about $60 \mathrm{~km}^{62}$. The hypothesis was contested later by Aladár Radnóti, which erroneously placed the northern frontier on Breaza peak alignment ${ }^{63}$ refuted in turn by the field research undertaken by I. Ferenczi ${ }^{64}$. Dumitru Tudor adopted in 1968 Panaitescu's position. He also stated that the northern area of the frontier of Dacia Porolissensis does not have in its system minor fortifications as those from the Porolissum area ${ }^{65}$; a baseless hypothesis, especially for the fact that already in 1959 , G. Forni stated that on the northern frontier, on a stretch of $10-25 \mathrm{~km}$ there are about 36 frontier installations spatially distributed in close connection with the landscape settings ${ }^{66}$.

In the 1930s, Constantin Daicoviciu began extensive field research on the course of the Meseș Mountains, from Bologa up to Porolissum - Brebi area (following K. Torma and Á. Buday earlier accounts) where he excavated inside the two turf and timber fortlets and a palisade segment ${ }^{67}$. His theoretical hypotheses are entirely opposed to the physical organization of the north-western frontier, as were postulated by his predecessors. In his opinion, the structures saw by K. Torma at Poieni are modern; there is no stone wall and the limes described by K. Torma and Á. Buday at Poieni and Buciumi is non-existing ${ }^{68}$. After his archaeological research, C. Daicoviciu states that the only linear frontier system is to be seen at Brebi, denying a complete linear frontier of a Germanic type in Dacia Porolissensis. The only physical organization consist of watchtowers, fortlets and forts, strategically located within the local relief ${ }^{69}$.

The 1940s witnessed a shift of perception and applied methodology for the research of the north-western frontier area of Dacia Porolissensis, generally conducted by the Hungarian Scholar Aladár Radnóti. Following his (somewhat) systematical archaeological research carried out within the auxiliary fort at Porolissum - Pomet ${ }^{70}$, Radnóti marked the pioneering of aerial photography applied on sites as a tool for mapping and identifying the archaeological features belonging to the Roman frontier from the Meses Mountains and Porolissum area ${ }^{71}$. With the Hungarian Military Aviation (1943) help ${ }^{72}$, he surveyed the area in question, subsequently publishing a comprehensive study about the archaeological feature connected to a frontier interpretation. The covered area stretches from Bologa - Poieni in the south up to Porolissum in the north, recording several watchtowers, probably a series of fortlets, linear fortification and auxiliary forts, mapping precisely for the first time the trajectory of the north-western frontier from the $\operatorname{air}^{73}$, confirming among other things, the structures described earlier by Torma and Buday ${ }^{74}$.

As we argued in a previous study ${ }^{75}$, I. Ferenczi's attempt to place Radnóti within the group of those who postulate the existence of a continuous linear frontier on the Meseș Mountains ${ }^{76}$ is not entirely valid. Although Radnóti is a supporter of the classic limes Dacicus concept, the hypothesis of an organized defence at the confines of Dacia ${ }^{77}$ has nothing to do with the theory mentioned above of a continuous vallum in the north-western area of Dacia Porolissensis.

With Radnóti's approaches, the Roman frontier research in Dacia Porolissensis from the first half of the $20^{\text {th }}$ century naturally moves on to the following generation of scholars; a generation that almost entirely included

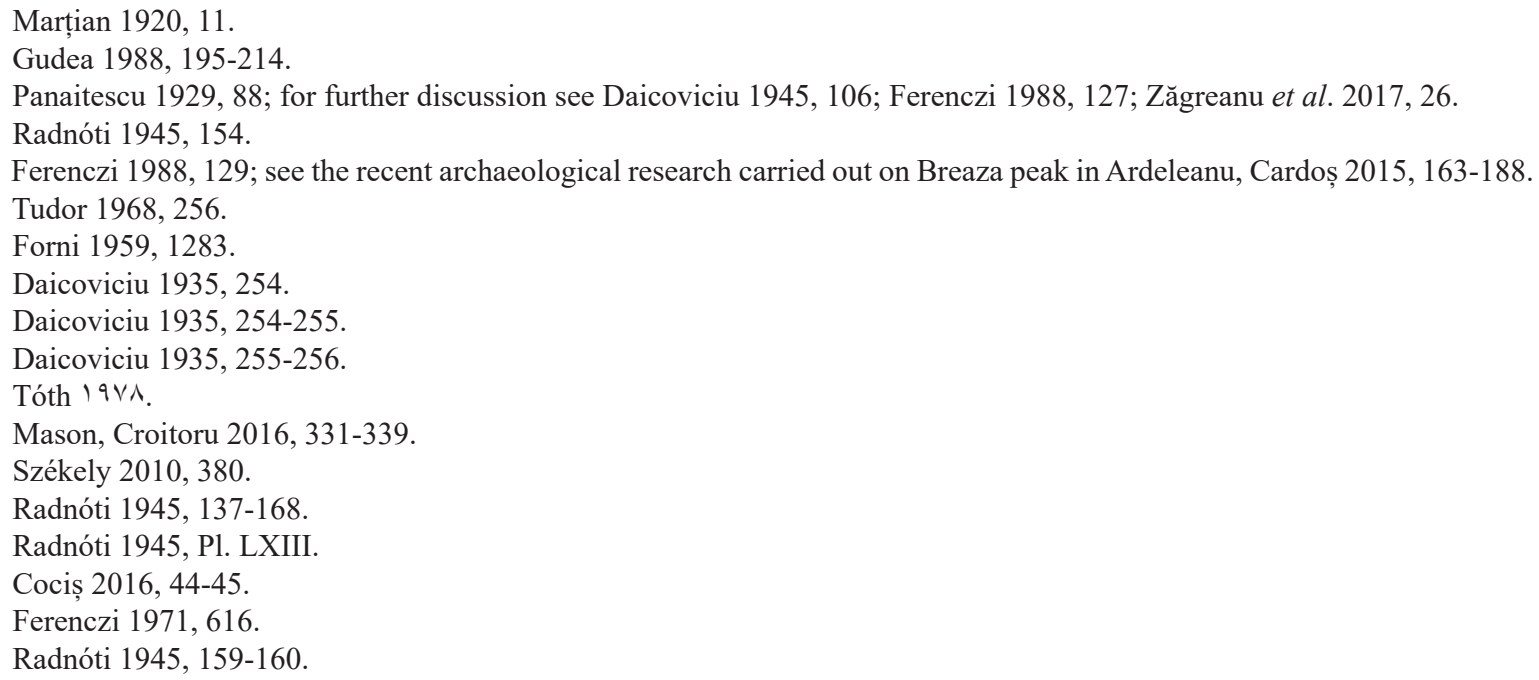


the work carried out by I. Ferenczi and N. Gudea, during the second half of the $20^{\text {th }}$ century. We must underscore the archaeological activity-focused (as secondary objectives) of M. Moga, who excavated a rectangular stone watchtower and a two-phased linear fortification at Porolissum ${ }^{78}$ and the systematic research of the fortlets and linear fortifications M. Macrea and hist team around Porolissum military and civil core ${ }^{79}$.

This is the background on which Ferenczi began his tremendous work: a fragmented field research on the frontier segment from the Meseș Mountains, physical frontier elements not correctly (and entirely) mapped at Porolissum, an almost complete survey gap on the northern and eastern frontier sector and the lack of a coherent definition and a viable, functional interpretation of the general framework of the frontier of Dacia Porolissensis and its minor and linear installations.

\section{Filling the gaps, creating the maps. Ferenczi's field surveys on the frontier of Dacia Porolissensis}

Naturally, Ferenczi started his field surveys and theoretical studies based on Torma's legacy in the north-west. His first results (at the very age of 20) are based on rigorous documentation. At this point, what differentiates him from his predecessors is not so much the applied field methodology (although several aspects are a complete novelty) but the fact that he was the first to offer a comprehensive theory and an interpretative framework of the north-western frontier of Dacia Porolissensis, the functionality of the frontier system being understood in entirely different parameters. The larger context in which he integrated his work permitted a more complex view of the limites framework.

In his first study mentioned above, he discussed theoretical approaches regarding the Roman frontier in Dacia Porolissensis, reviewing all the theories up to $\mathrm{him}^{80}$. The early field surveys were conducted only in the Porolissum area, mapping the western part of the military and civil centre's inner fortification line, the turf and timber fortlets and palisade at $\mathrm{Brebi}^{81}$ and the so-called doublewall segment ${ }^{82}$ (the aqueducts of Porolissum ${ }^{83}$ ). As topographic support, Ferenczi used a general map based on the Third Military Mapping Survey of Austria-Hungary (1869-1885), a singular case in the Roman frontier's bibliography about Dacia Porolissensis ${ }^{84}$. His training as a geographer was intertwined with the classical, archaeological and historical studies, the topographic surveys of the sites, and the spatial mapping of the minor and linear frontier fortifications, being extremely accurate and valuable in understanding the building process of the frontier.

The research of the north-western sector undergoes a relatively long temporary hiatus, Ferenczi focusing now on an unknown (yet provocative) area: the western frontier of Dacia Porolissensis. The systematic surveys were carried out between 1947-1957, and in 1966, the covered area stretching between the auxiliary forts at Bologa (Cluj County) and Gilău (Cluj County). The first part of the results comprising the description of the landscape settings and the possible archaeological features were mentioned and contextualized in $1959^{85}$. The rest of them only later, between

78 Moga 1950, 134.

79 Macrea et al. 1961, 366-367; Macrea et al. 1962, 493-494.

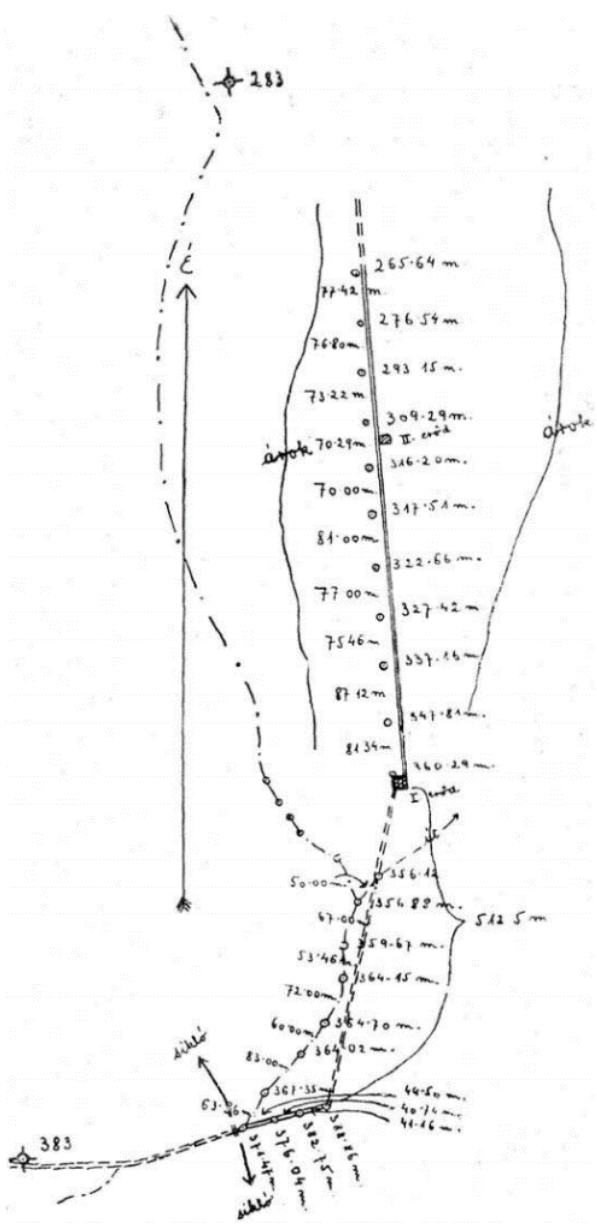

Fig. 4. The turf and timber palisade and fortlets at Brebi. The topographic survey of I. Ferenczi made in 1941 (after Ferenczi 1941, 196, Fig. 6).

80 Ferenczi 1941, 189-190.

81 Ferenczi 1941, 194-199.

82 See in this direction the full discussion in Goos 1876, 218-226; Buday 1912, 99-119; Marțian 1920, 27, 29; Ferenczi 1941, 191-199; Radnóti 1945, 145; Daicoviciu 1953, 265; Macrea et al. 1962, 494-495; Gudea 1989, 107, 111; Matei 1995, 56; Matei 2005, 293-311; Cociș 2016, passim; Nedelea et al 2019, 196.

83 Matei 2005, 293-311.

84 The extended map in Ferenczi 1941, Fig. 1.

85 Ferenczi 1959, 337-354. 


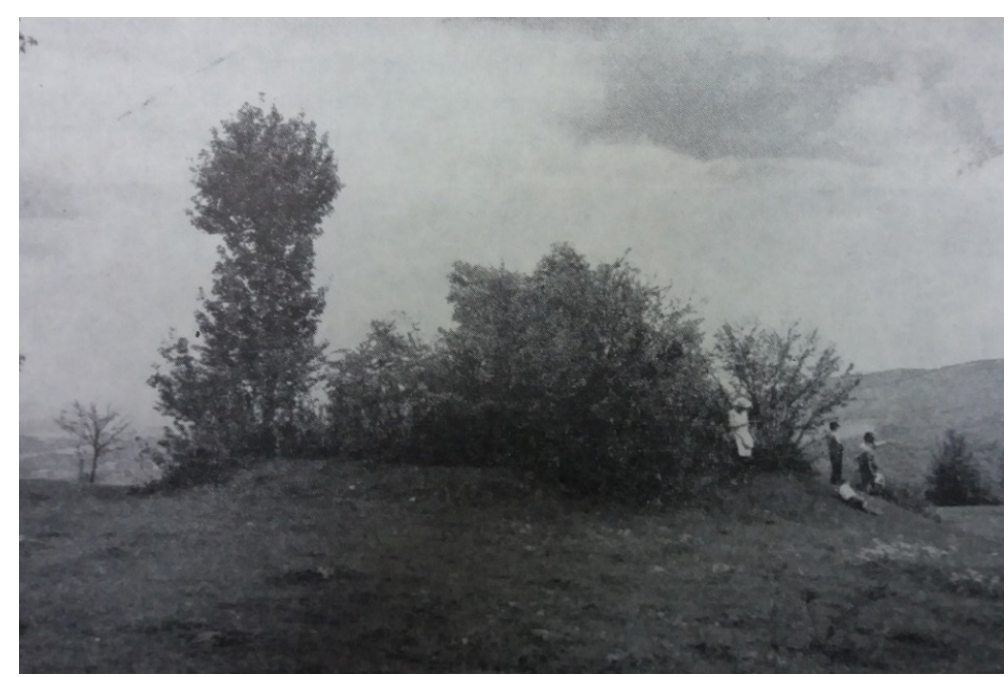

Fig. 5. The ruins of a stone watchtower near Agrij village (Sălaj County) photographed by I. Horváth in 1964 (after I. Ferenczi 1967, 149, Fig. 5).
1972-1974 ${ }^{86}$. The situation of the western frontier, as Ferenczi described, is still at the same stage, the gap between the auxiliary forts at Bologa and Gilău still being a desideratum. The situation changes west of the legionary fortress at Potaissa; a limitroph area was researched during the last decades, the discoveries and the archaeological excavations outlining an active rural hinterland with settlements specialized in stone and gold extraction ${ }^{87}$. A similar situation at a smaller scale was outlined on the course of the Somes River, on the trajectory of the Roman road between the auxiliary forts at Samum and Arcobara $^{88}$.

However, when Ferenczi was involved in the western frontier area survey, the north-western sector (especially

Porolissum) was archaeologically researched in several critical points by M. Moga, M. Macrea and his team. After this brief episode, the north-western field research carried out by Ferenczi returns to the forefront. During the 1960s, he undertook a massive survey on the course of the Meseș Mountains, mapping and describing every minor and linear fortification between the auxiliary fort at Bologa and Tihău, focusing this time on the watchtowers, mapping about 50 structures, four fortlets and several linear fortifications (besides the two structures from Brebi, he accurately mapped for the first time the fortlet at Dealul Secuiului ${ }^{89}$ and Poic - La Arie $^{90}$, based on Buday's survey ${ }^{91}$ ). The surveys are combined with field photography applied on a large scale, made by the renown photographer I. Horváth. The results were published in 1967 in a comprehensive study ${ }^{92}$; Ferenczi’s last field research-based contribution on the north-western frontier sector.

Interspersed with the research of the north-western and northern sectors, Ferenczi undertakes a series of surface and archaeological research in the eastern part of Transylvania, on the eastern frontier sectors, first at Băile Homorod area $^{93}$ and later (being also his prior studies on the subject), within the eastern frontier stretches between the auxiliary forts at Brâncovenești - Călugăreni, Călugăreni (Mureș County) - Inlăceni (Harghita County) and between Homorod Valey - Tuşnad (Harghita County) $)^{94}$.

After 1968, Ferenczi started the long journey searching for the northern and north-eastern frontier of Dacia Porolissensis, a blind survey on the north-eastern extremities of Sălaj County and the north and north-eastern areas of Bistrița-Năsăud County. During 1968, 1969 and 1971, he started the identification and mapping process of the minor frontier fortification between the auxiliary fort at Tihău (Sălaj County) and Ileanda (Sălaj County) ${ }^{95}$, on the course of the Someș river, as well as north of this line where a series of archaeological features were considered advanced outposts of an outer frontier ${ }^{96}$, a theory created on inconclusive arguments ${ }^{97}$.

Based on several earlier accounts of Torma ${ }^{98}$ and Kádár ${ }^{99}$, Ferenczi managed to accomplish an almost blind survey process, identifying the minor frontier fortifications, completing considerable gaps in the stretches between Ileanda and the auxiliary fort at Samum and then between the mentioned fort and Salva (Bistrița-Năsăud County),

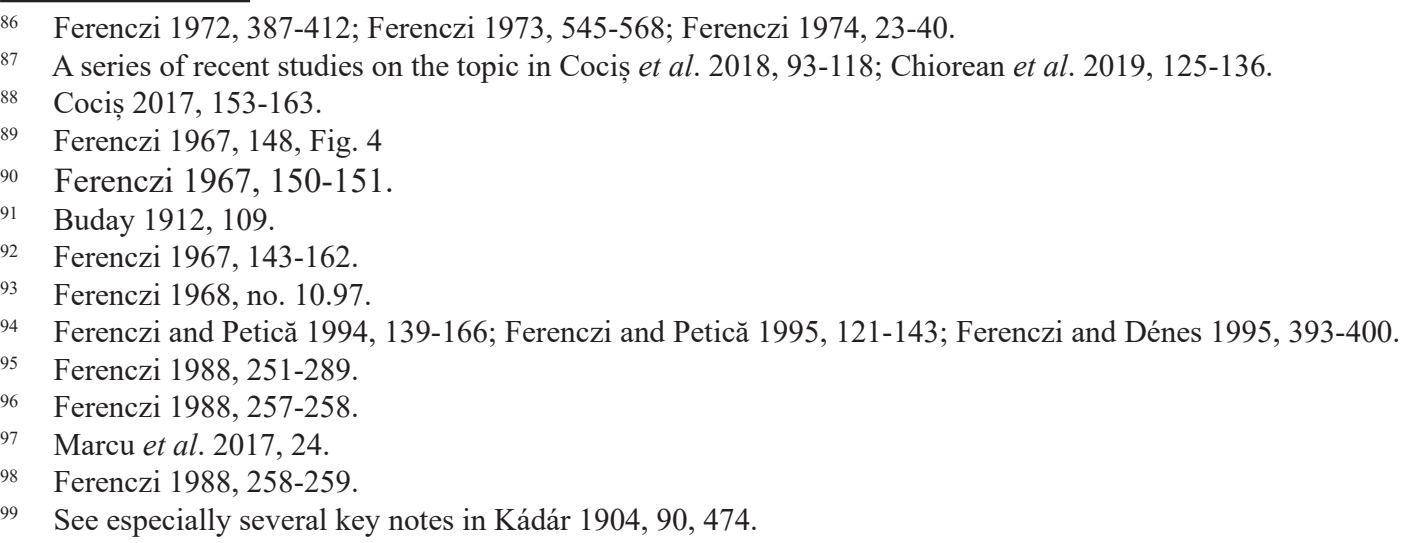



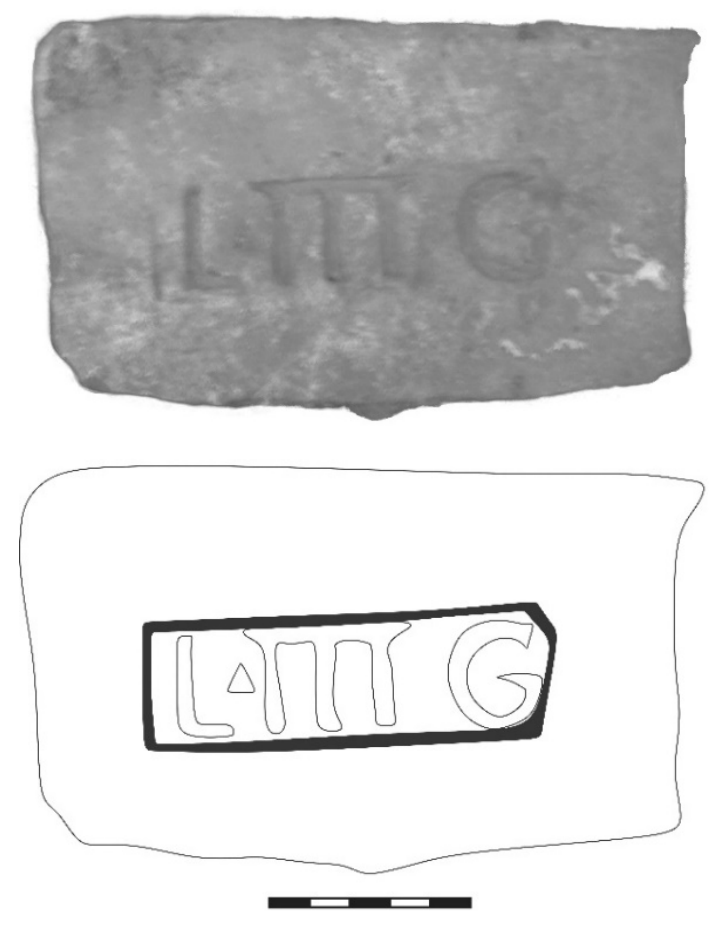

Fig. 6. The stamped brick of legio III Gallica discovered by Ferenczi at the stone watchtower from Cetate 1 (after Cociș 2018a, 404, Fig. 5). intensifying the research in front of the auxiliary fort at Arcobara. The surveys and the mapping process between the 1970s and the 1980s were published in a series of studies containing geographical interpretation, accurate maps and photos of the archaeological features ${ }^{100}$.

Even if the mapping process was a slow yet accurate one, the archaeological research undertook by Ferenczi was at a significantly reduced scale, compared, for example, with the systematic research conducted by N. Gudea from 1966 to 1988 , who excavated almost entirely around 66 minor fortifications and three linear ones. ${ }^{101}$ However, some of the features received more attention from Ferenczi. We briefly mentioned his extensive excavation from the watchtower called Cetate 1 (Bârsău Mare, Sălaj County). ${ }^{102}$ He identified a damaged stone structure, potsherds and a stamped brick of legio III Gallica. ${ }^{103}$ Their headquarters were identified at Porolissum (approx. $40 \mathrm{~km}$ south-west). ${ }^{104}$

Fig. 6. The stamped brick of legio III Gallica discovered by Ferenczi at the stone watchtower from Cetate 1 (after Cociș 2018a, 404, Fig. 5).

Another example is the square stone watchtower at Hotroapă (Căpâlna, Sălaj County) ${ }^{105}$, where a two-phased structure was investigated utilizing a median archaeological trench. In the second stone phase, a denarius minted during Lucius Septimius Geta was found, now lost $\mathrm{t}^{106}$. The most iconic discovery during his surface surveys is, without doubt, the fragmentary inscription found near the stone fortlet at

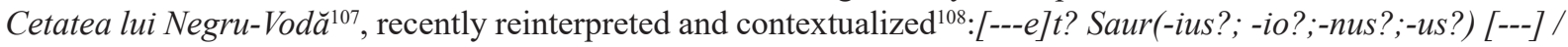
[---] mile $[s]^{109}$.

Over about 50 years, Ferenczi managed to identify and map around 130 watchtowers, nine fortlets and seven distinct segments of linear fortifications (turf and timber palisade and stone walls). Regarding this part, he covered by foot a vast area of the Roman frontier in Dacia Porolissensis, covering five counties and hundreds and hundreds of kilometres. The gaps covered and populated with mapped archaeological features remains up to present a valuable
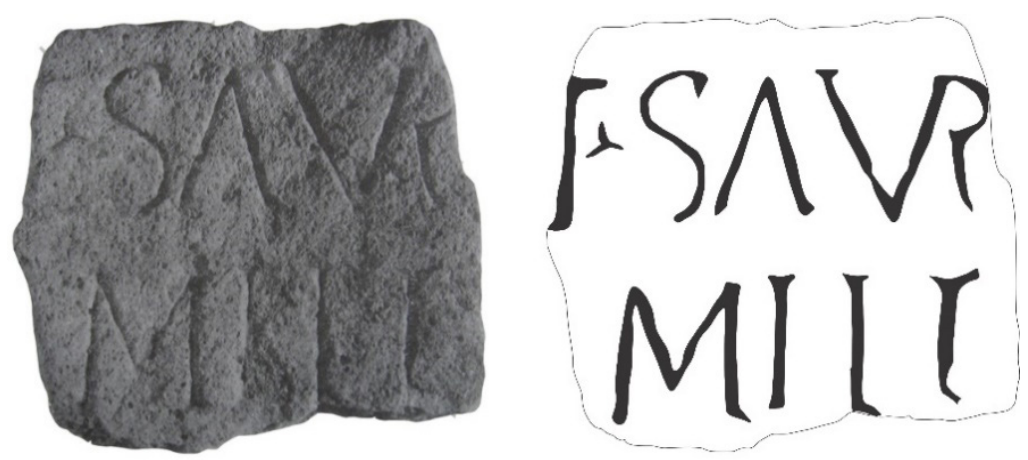

Fig. 7. The inscription from the stone fortlet at Cetatea lui Negru-Vodă (photo after Ferenczi 1973, 97, Fig. 10; drawing after H. Cociş 2016a, 67, Fig. 7). cartographic source for every repertoire containing the elements of the Roman frontier in northern Dacia.

\footnotetext{
100 Ferenczi 1971, 73-84; Ferenczi 1972, 37-46; Ferenczi 1973, 79-104; Ferenczi 1974, 181-189; Ferenczi 1975, 285-289; Ferenczi 1976, 107-133.

101 See especially Gudea 1980, 661-663; Gudea 1985, 143-218; Gudea 1997.

102 Kádár 1900, 512; Ferenczi 1991, 137; Marcu et al. 2017, 21, Fig. 1; Cociș 2018a, 403-404.

103 Cociș 2018a, 403-404.

104 A recent discussion with the older bibliography in Piso and Deac 2016, 11.

105 Ferenczi 1991, 139-140; Marcu et al. 2017, 21, Fig. 1.

106 Ferenczi 1991, 140.

107 Kádár 1901, 222; Marțian 1920, 28; Marțian 1921, 23-24; Ferenczi 1973, 95; Cociș 2016a, 53-67; Zăgreanu et al. 2017 , 30; Cociș 2018b, 41-42.

108 Cociș 2016a, 53-67.

109 Cociş 2016a, 67, Fig. 7.
} 


\section{Quelques précisions concernant la notion de limes. Ferenczi's interpretations on the functionality of the Roman frontier.}

In order to draw Ferenczi's theoretical background concerning the interpretative fashions regarding the physical organization of the Roman frontier in northern Dacia, we must outline its critical points in relation to the main European theories he emphasized and used at that time ${ }^{110}$.

Ferenczi's theoretical framework for understanding and interpreting the Roman frontier in general and the northern Dacia stretch in particular could be observed almost in every study regarding different stretches, but, most of all, in two particular papers ${ }^{111}$ (and one presentation ${ }^{112}$ ). In his synthesis from 1971, Ferenczi shook and reinterpreted the theoretical functionality of the classic concept of limes Dacicus, using a broad bibliographic spectrum combined with a variety of epigraphic and literary sources mainly from the western and eastern provinces ${ }^{113}$; there is no doubt that this is the first exhaustive Roman frontier analysis from the Transylvanian frontier studies.

Based on the analysis of the sources mentioned above, Ferenczi considered that the so-called limes was initially a military road, then a sort of fortification consisting of artificial barriers (where local politics and factors dictate the need) and finally, although he does not literarily apply the theory of regiones, considers that starting with the late Roman period, the administration and the security of the frontier stretches is ensured by duces and praepositi ${ }^{114}$. Ferenczi's conclusions on the functionality and evolution of the Roman frontier as a whole anticipates to a large extent the subsequent study conducted by Benjamin Isaac and published in $1988^{115}$. Here it is demonstrated (and now more and more questioned ${ }^{116}$ ) the hypothesis that the limes underwent crucial metamorphoses in its conceptual and physical framework and operating system ${ }^{117}$ during the $1^{\text {st }}-4^{\text {th }} \mathrm{c}$. AD, from a primary military road subsequently equipped with linear fortifications to an anthropic barrier such as Hadrian's Wall or the ORL, to the final use of the administrative security regiones ${ }^{118}$.

The approaches of Ferenczi to a theoretical model of the Roman frontier is primarily inclined towards what Edward Luttwak defined later as preclusive defence - forward defence ${ }^{119}$ concept. He considered that the Empire used, during the Principate (30-284 AD) and developed a general military strategy meant to neutralize the spotted enemy before crossing the frontier, the central conflict area being thus the Barbarian vorlimes in the vicinity of the state physical limites. From the $3^{\text {rd }}$ century AD onward, Luttwak believes that the Empire's strategy undertook significant policy changes, appearing the so-called concept of defence - in - depth which involves military movements to neutralize the enemy on Roman territory, turning the frontier into an area of potential conflict ${ }^{120}$. This particular theory of Luttwak reflects on the late Roman frontiers' economic dynamism and was harshly criticized by several leading theorists of the Roman frontier studies.

Another crucial interpreting direction observed at Ferenczi to a certain extent is what J. C. Mann defined as mobility support. According to Mann, the frontier's architecture and the general operating principles generate and support the military factor's mobility along the frontier lines to ensure security and stop potential conflicts. This particular aspect is, in his opinion, the basis of the entire Roman frontier system ${ }^{121}$.

However, what differentiates Ferenczi is that extensive and systematic field research doubles his theoretical spectrum based on which the theories regarding the frontier's modus operandi are subsequently stated. To summarize the conclusions of his research on the concept of limes as a comprehensive approach, we outline that in his view, the frontier is organized in the form of a strip composed of a military road that connects the frontier auxiliary forts, doubled by watchtowers on the high grounds and fortlets in the valleys and crossing points - their role is to survey and control the traffic routes and the access ways into the Empire ${ }^{122}$.

\footnotetext{
110 Ferenczi 1971, 600-601, note 1; see Mommsen 1885, 43-51; Mommsen 1894, 134-143; Mommsen 1908, 444-452; Cagnat 1892 and especially Piganiol 1963, 119-122.

111 Ferenczi 1968, 65-98; Ferenczi 1971, 588-625.

112 Le systéme et le caractére du soi-distant „Limes Dacicus”. The resumes of papers read at $7^{\text {th }}$ International Congress for Roman Frontier Studies, Tel Aviv University, Israel, 1967.

113 Ferenczi 1971, 600-612.

114 Ferenczi 1971, 603-607.

115 Isaac 1988, 125-145.

116 Symonds 2018.

117 Isaac 1988, 146-147.

118 Isaac 1988, 132-138.

119 Luttwak 1976, 51-126

120 Luttwak 1976, 127-190

121 Mann 1974, 508-533.

122 Ferenczi 1971, 608-612.
} 
According to the more recent paradigms, Ferenczi's conceptions may seem outdated and unjustified. However, even some general theories shifted the paradigms in the more recent period. Several of Ferenczi's observations fit perfectly into the newer trends regarding the particular operating system of the frontier of Dacia Porolissensis, even 50 years after their publication.

\section{How the frontier of Dacia Porolissensis worked? The theoretical model of Ferenczi.}

The general framework and functioning model emphasized by Ferenczi was, naturally, extrapolated within the confines of the studied area, creating thus a new theoretical model based on field surveys and archaeological evidence, also cancelling the theories launched by Buday and Finály. Their mechanical methods of importing the ORL physical realities in Dacia Porolissensis but especially their denial of the Roman character of the discoveries made by Torma (and by them), were severely criticized.

The fact that the two scholars imported a theory based on the operating principles of a linear frontier par excellence in the north-western area of the Province of Dacia Porolissensis, denying the archaeological evidence effectively, made Ferenczi accuse them of gross mistakes, even the distortion of the archaeological reality ${ }^{123}$. He challenged Domaszewski's theory according to the northern Dacian limes is of a Talsperren - type (a theory that automatically disregards the field discoveries as being of a completely different nature) ${ }^{124}$. However, he is tributary to Daicoviciu's observations regarding the non-existence of a continuous linear fortification on the Meseș Mountains ${ }^{125}$.

Through his extensive field surveys, Ferenczi understood the frontier of Dacia Porolissensis as a defensive system built mainly following the local landscape settings (giving too much credit to what we now call geographic determinism or environmental determinism ${ }^{126}$ ). The frontiers of the Roman Empire are not entirely built on the local geographical coordinates. However, the landscape settings ${ }^{127}$ are combined with the so-called localism ${ }^{128}$, a quantum of internal and external factors (the landscape, the raw material, the strategic crossing points, the human dynamics, the mobility of the troops, etc.) that generate particular frontier types in each Province, according to the local situation as a whole. The so-called limites are not an automatic byproduct of the Roman conquest but rather a response to the political status-quo generated by particular regional human dynamics ${ }^{129}$.

In order to draw a red line through Ferenczi's theories regarding the modus operandi of the north-western frontier of Dacia Porolissensis, we applied a synoptic rendering in a tabular model in order to illustrate the fundamental ideas of his core theory.

Challenging Domaszeswki's theory is a natural consequence of the extensive field surveys, a complexity being observed in the distribution patterns. The more populated the map, the better the complexity and the localism of the frontier system in Dacia Porolissensis is observed, mainly because we deal primarily with a so-called mountain frontier type. This system explores the local topography to boost the tactical elements combined in the most vulnerable areas with linear barriers templates ${ }^{130}$.

Based on this, it is more than logic as the Porolissum area to have a complex surveillance system. What Ferenczi did not observe at that time is that the so-called multiple defence lines of Porolissum ${ }^{131}$ are actually two different surveillance and security systems, one belonging to the frontier and one the military and civilian core ${ }^{132}$, aspect to which we add the multiple phases and horizontal stratigraphy of the system, evolving through decades and moving its original location ${ }^{133}$. The watchtowers location at a short distance, as Ferenczi correctly noted, is necessary to create a viable communication system functioning in an optimal framework, hence the density in a particular distribution line ${ }^{134}$.

The high-security system of Porolissum fulfil several leading roles; one is to survey and control the main access route in the Province through the narrow pass of the Meseş Gate. It is not a coincidence that the same valey is

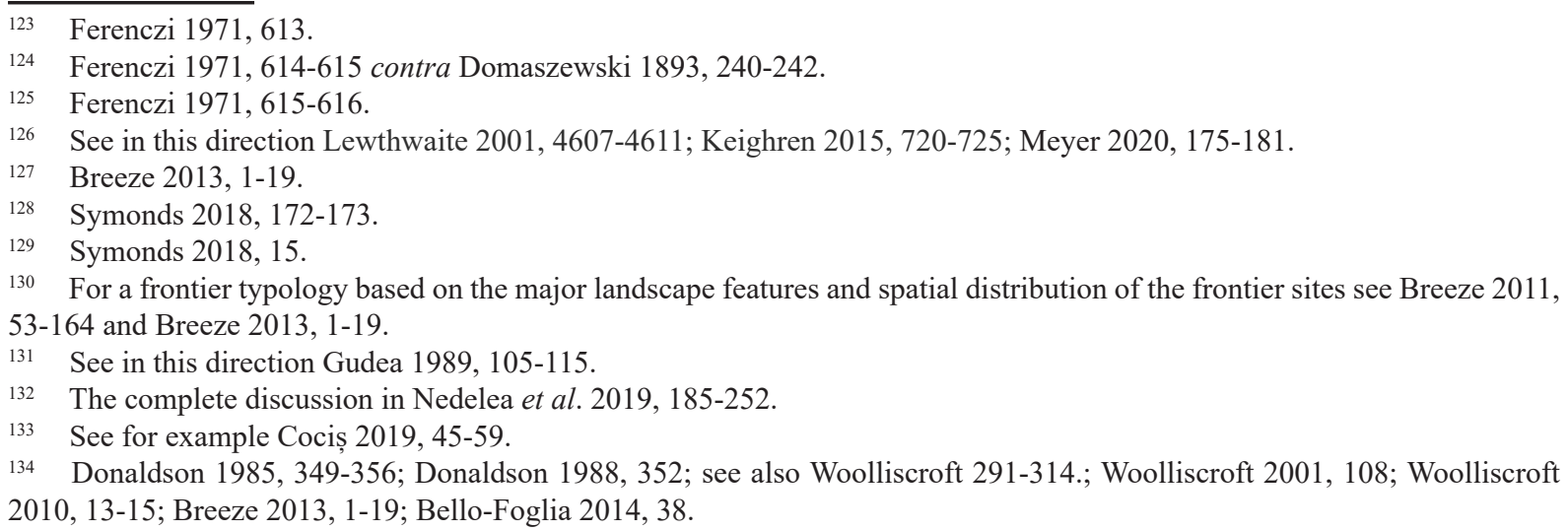




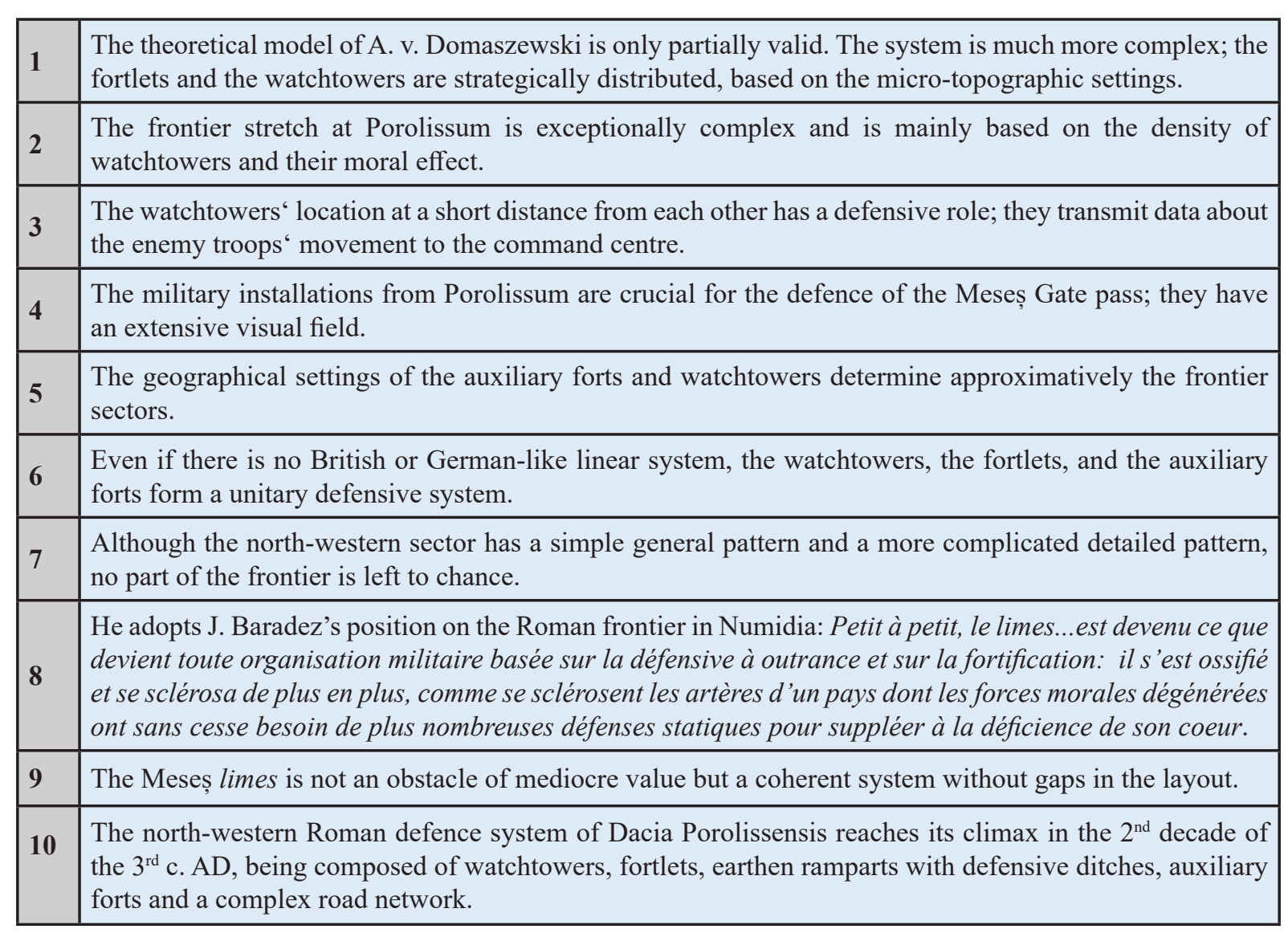

Tab. 1. Ferenczi's theoretical model of the north-western frontier of Dacia Porolissensis. Key ideas.

surveyed and controlled by two stone watchtowers, a stone fortlet and a $3.5 \mathrm{~km}$ wall, with multiple phases ${ }^{135}$. There is no possibility of determining the particular distinct sectors based on the spatial distribution of the minor fortifications. The military stamps could be a possibility but only combined with other geostatistical data and when their number will be higher than now ${ }^{136}$.

The so-called unitary defensive system of Ferenczi, distinct from the German or British frontier type, is primarily a local response to a specific local situation, a pattern adaptation to the condition encountered by the Roman army in this area. It is not an automatic product, but a particular system created to fulfil the particular security necessities of Dacia Porolissensis.

The entire coverage of the frontier area and a regular distribution pattern of the frontier installations within the limites of Dacia Porolissensis indicate an extensive scale security control that generates a main chain line of watchtowers, doubled by extra-security elements within the most vulnerable areas and access corridors. The Meses Mountain frontier sector is a typical example of a mountain frontier type. Due to its geographical and geomorphological layout, the continuous mountain line represented an optimal condition for the Roman topographers to create a chain line of towers on almost every higher peak with fortlets in the access valleys and linear fortifications within the hot areas $^{137}$.

It is prematurely to talk about a climax of the frontier system in Dacia Porolissensis mainly due to the lack of chronological values. However, there cannot be neglected several aspects such as a density of archaeological material generally dated in the second part of the $2^{\text {nd }} \mathrm{c}$. $\mathrm{AD}$ within the minor frontier installations.

\section{Instead of conclusions}

The aim of this short excursus through Ferenczi's research activity on the frontier of Dacia Porolissensis, covering around 50 years, was to highlight his main achievements but, most of all, to review the vast impact that he had on

\footnotetext{
135 Cociș and Bejinariu 2019, 83-102.

136 Cociș 2018a, 399-415.

137 Cociş 2018, 34-77.
} 
the Roman frontier studies in Romania both in the field studies and theoretical approaches.

Almost contemporary with him, N. Gudea took a step forward and began extensive archaeological excavations on the minor fortifications located between the auxiliary forts at Bologa (Cluj County) and Tihău (Sălaj County), confirming or refuting previous observations and comments made by Ferenczi. The combined yet different approaches of the mentioned archaeologists form, without question, the complex matter, the central pillar of the $20^{\text {th }}$ c. Limesforschung in Transylvania.

As we previously mentioned, it is more than usual to challenge some of Ferenczi's theories today because the Roman frontier studies evolved so much over the last two decades, creating a novelty of data and interpretations together with several new accepted paradigms. The paradigm shift is not possible without previous research, as Ferenczi did with the accepted theories of Buday and Finály.

\section{BIBLIOGRAPHY}

Ambrus, L. 2000. In Memoriam - Ferenczi István Mihály. Hazanézö 11, 2: 2.

Ardevan, R. 1977. Vestigii arheologice sălăjene semnalate la 1859. AMP 1: 129-134.

Ardeleanu, M. and Cardoș, R. 2015. Raport privind cercetările de suprafață şi sondajele efectuate pe Culmea Breaza / județul Maramureș (I). Marmatia 12: 163-188.

Bello Folgia, A. 2014. Turrets as watchtowers on Hadrian's Wall: a GIS and source-based analysis of appearance and surveillance capabilities. Archeologia Aeliana 43: 27-46.

Boda, I. 2013. Torma Károly (1829-1897) and the archaeological research in Dacia. Case study: Ilişua. REDIVA 1: 75-104.

Breeze, D. 2011. The Frontiers of Imperial Rome. Barnsley: Pen \& Sword.

Breeze, D. 2013. Roman frontiers in their Landscape Settings. Newcastle: The Literary and Philosophical Society of Newcastle upon Tyne.

Buday, A. 1910. A római limes Németországban. Tanulmányúti beszámoló. Dolgozatok 1: 1-117.

Buday, A. 1912. Vannak-e limes maradványok a Meszesen? Dolgozatok 3: 103-118.

Buday, A. 1914. Limes-maradványok Porolissum környékén. Dolgozatok 4: 95-105.

Buday, A. 1936. Erdély földjének római kora, in Asztalos, M. (ed.) A történeti Erdély:127-147. Budapest: Hungária Nyomda R.T.

Cagnac, R. 1892. L'armée romaine d'Afrique et l'occupation militaire de l‘Afrique sous les empereurs. Paris: Imprimerie nationale.

Chiorean, P., Cociş, H. and Bere, B. 2019. The Secondary Roads of Potaissa. Case Study II: Trial Trench on the Road Segment from Livadă-Valea Agrișului-Iara (Cluj County). Ziridava 33: 125-136.

Cociș, H. 2016. Linear Fortifications on the North-Western Frontier of Dacia Porolissensis, in V. Bârcă (ed.), Orbis Romanus and Barbaricum. The Barbarians around the Province of Dacia and Their Relations with the Roman Empire: 41-76. Cluj-Napoca: Mega Publishing House.

Cociș, H. 2016a. Limitis Provinciae Daciae Porolissensis. Negrilești (jud. Bistrița - Năsăud). Buletinul Cercurilor Științifice Studențești 22: 53-67.

Cociș, H. 2017. The Rural Landscape of the Frontier of Dacia Porolissensis. A Case Study: the Northern Sector - territorium Arcoba(da)rense - The Valley of River Someșul Mare. Ziridava 31: 153-163.

Cociş, H. 2018. Archaeologia Porolissensia. Repere generale în cercetarea epocii romane de pe teritoriul județului Sălaj, in Băcueț-Crișan, D., Băcueț-Crișan, S., Bejinariu, I., Pop, H., Cociș, H., Deac, D. (eds.). 100 de ani de cercetări arheologice în Sălaj: 117-143. Cluj-Napoca: Mega Publishing House.

Cociş H. 2018a. Some Considerations on the Brick and Tile Stamps from the Frontier Watchtowers of Dacia Porolissensis, in S. Forțiu (ed.) Arheovest VI. Interdiciplinaritate in arheologie. In memoriam Marian Gumă: 399-415. Szeged: JATEPress Kiadó.

Cociș, H. 2018b. The Fortlets on the Frontier of Dacia Porolissensis. Structures, Landscape, Functionality. Studia Universitatis Babeș-Bolyai 63, 1: 34-77. 
Cociș, H., Chiorean, P. and Ciobanu, C. 2018. The Secondary Roads of Potaissa. Case Study: A new Road Segment from Livadă-Valea Agrișului-Iara (Cluj County). Ziridava 32: 125-136.

Cociș, H. and Bejinariu, I. 2019. Recent Archaeological Excavations in the Meseș Gate Pass (Dacia Porolissensis, Sălaj County). The Roman Frontier Watchtower from Poguior Hill. Cercetări Arheologice 16: 83-102.

Cupcea, G. 2014. Professional Ranks in the Roman Army of Dacia. Oxford: BAR Publishing.

Daicoviciu, C. 1935. Dacica. În jurul unor probleme din Dacia romana II. Există un limes dacicus în Munții Meseșului. Anuarul Institutului de Studii Clasice 2: 240-256.

Daicoviciu, C. 1945. La Transylvanie dans l'Antiquite. Bucharest: București Publishing House.

Deac, D. and Dana, D. 2019. Liber Pater Frugifer: un graffite votif du camp auxiliaire de Romita (Dacia Porolissensis). Acta Musei Porolisensis 41: 113-120.

Dénes, I. 2000. In memoriam Ferenczi István Mihály (1921-2000). Erdővidéki lapok 1: 18-21.

Domaszewsi, A. von. 1893. Zur Geschichte der römischen Provinzialverwaltung. Dacia. Rhein Museum 48: 240-244.

Donaldson, G. 1985. Roman Military Signaling on the North British Frontier, Archeologia Aeliana 13: 19-24.

Donaldson, G. 1988. Signalling Communications and the Roman Imperial Army. Britannia 19: 349-356.

E. Fabricius, Limes, Realencyclopädie der classischen Altertumswissenschaft 13, col. 572-671 [Donauprovinzen: col. 634-650].

Ferenczi, I. 1941. Régészeti megfigyelések a limes dacicus szakaszán. Erdélyi Múzeum 41: 189-214.

Ferenczi, I. 1959. Contribuții la problema limesului de vest al Daciei (I). Studii și Cercetări de Istorie Veche 10: 337-354.

Ferenczi, I. 1967. Die erforschung des römischen Limes auf den Höhen des Meseș-Gebirges. (Ein Vorbericht). Dacia. Revue d'archéologie et d'histoire ancienne, Nouvelle Serie 11: 143-162.

Ferenczi, I. 1968. Observații cu privire la sistemul și caracterul așa-zisului „Limes Dacicus”. Acta Museii Porolissensis 5: 75-98.

Ferenczi, I. 1971. Câteva precizări în legătură cu noțiunea de Limes Dacicus. Apulum 9: 599-625.

Ferenczi, I. 1972. Cercetări și rezultate noi pe limes-ul de nord a Daciei Romane. File de Istorie 2: 37-46.

Ferenczi, I. 1973. Contribuții la cunoașterea limes-ului roman la nord de Someșul Mare. Partea I. Sargetia 10: 79-105.

Ferenczi, I. 1974. Investigații noi pe limes-ul de nord și nord-est al Daciei Porolissensis. File de Istorie 3: 181189.

Ferenczi, I. 1975. Limes-ul Daciei Porolissensis între Valea Zagrei și Valea Mureșului. Sargetia 11-12: 285-289.

Ferenczi, I. 1976. Contribuții la cunoașterea limes-ului roman de la nord de Someșul Mare. Partea a II-a. File de Istorie 4: 107-133.

Ferenczi, I. 1988. Limes-ul Daciei. Sectorul de pe Someșul (Unit). Elemente de apărare pe subsectorul IleandaTihău. Acta Museii Porolissensis 12: 251-289.

Ferenczi, I. 1991. Limes-ul Daciei. Sectorul de pe Someșul (unit). Elemente de apărare de pe sub-sectorul CășeiIleanda. Acta Museii Napocensis 14-15: 127-151.

Ferenczi, I. and Dénes, I. 1995. Investigarea unei porțiuni de limes din estul Daciei intracarpatice (între Valea Homorodului și Defileul Oltului de la Tusnád). Acta Museii Napocensis 32, 1: 393-400.

Ferenczi, I. and Petică, M. 1994. Limes-ul Daciei. Contribuții la cunoașterea sectoarelor Brâncovenești Călugăreni și Călugăreni - Sărățeni (jud. Mureș) (I). Apulum 31: 139-166.

Ferenczi, I. and Petică, M. 1995. Limes-ul Daciei. Contribuții la cunoașterea sectoarelor Brâncovenești Călugăreni și Călugăreni - Sărățeni (jud. Mureș) (II). Apulum 32: 121-143.

Finály, G. 1904. A limes Dacicus és a pugujori földvár. Archaeologiai Értesitö 24: 9-15.

Florea, G. 2016. Despre temple, hambare și arheologia ritualului, Analele Banatului 26: 221-231.

Forni, G. 1958. Limes, in E. de Ruggiero (ed.) Dizionario Epigrafico di Antichità IV, 34-40, 1074-1280. Roma:

L. Pasqualucci.

Gaiu, C. 2012. Patrimoniul transilvănean în corespondența lui Iulian Marțian. Revista Bisistriței 26: 113-155. 
Gáll, E. 2014. Precursorii arheologiei profesioniste din Transilvania. Gábor Téglas. Studii și Cercetări de Istorie Veche și Arheologie 65, 3-5: 219-293.

Goos, C. 1976. Chronik der archäologischen Funde Siebenbürgens. Im Auftrage des Vereins für siebenbürgische Landeskunde. I. Funde aus vorrömischer Zeit. II. Funde aus der Zeit der Römerherrschaft. III. Funde aus der Zeit der Völkerwanderung. Sibiu: Archiv des Vereins für Siebenbürgische Landeskunde XIII/1.

Gudea, N. 1980. Cercetările de teren și săpăturile arheologice efectuate pe linia de turnuri din sectorul de nordvest al limesului Daciei. Materiale și Cercetări Arheologice 14: 661-663.

Gudea, N. 1985. Contribuții la istoria militară a Daciei Porolissensis. I. Linia înaintată de turnuri și fortificații mici de pe sectorul de nord-vest al limesului provinciei între castrele de la Bologa și Tihău. Acta Museii Porolissensis 9: $143-218$.

Gudea, N. 1988. Porolissum cheia de boltă a apărării Daciei Porolissensis. Acta Museii Porolissensis 12: 195-214. Gudea, N. 1989. Porolissum. Un complex arheologic daco-roman la marginea de nord a Imperiului Roman I. Cercetări și descoperiri arheologice până în anul 1977. Acta Musei Porolissensis 13: 1-1178.

Gudea, N. 1997. Der Meseș - Limes. Die vorgeschobene Kleinfestungen auf dem westlichen Abschnitt der Grenze der Provinz Dacia Porolissensis / Linia înaintată de turnuri de pază de pe sectorul de vest al provinciei Dacia Porolissensis. Zalău: Muzeul Județean de Istorie și Arheologie Zalău.

Isac, D. 1994. Vicus Samum - eine statio der Beneficiarier an der nördlichen Grenze Dakiens. Der Romische Weihebezirk von Osterburken II: 205-215.

Isac, D. 2003. Castrul roman de la SAMVM - Cășeiu. Cluj-Napoca: Napoca Star.

Isaac, B. 1988. The meaning of the terms "limes" and "limitanei". The Journal of Roman Studies 78: 125-147.

Kádár, J. 1900. Szolnok-Doboka vármegye monographiája III. Dej: Kiadja Szolnok-Dobokavármegye közönsége.

Kádár, J. 1901. Szolnok-Doboka vármegye monographiája V. Dej: Kiadja Szolnok-Dobokavármegye közönsége.

Kádár, J. 1904. Szolnok-Doboka vármegye monographiája VII. Dej: Kiadja Szolnok-Dobokavármegye közönsége.

Keighren, I., M. 2015. Environmental Determinism, in Wright, J., D., (ed.), International Encyclopedia of the Social and Behavioral Sciences: 720-725. Orlando (Florida, US): Elsevier.

Lewthwaite, G., R. 2001. Enviromental Determinism, in Neil J. Smelser and Paul B. Baltes (eds.) International Encyclopedia of the Social \& Behavioral Sciences: 4607-4611. Orlando (Florida, US): Elsevier.

László, G. 1996. Egy régészélet dicsérete (Laudă unei vieți de arheolog). Specimena Nova 12: 7-14.

Luttwak, E. N. 1976. The Grand Strategy of the Roman Empire from the First Century AD to the Third. Baltimore: John Hopkins University Press.

Macrea, M., Rusu, M. and Mitrofan, I. 1961. Șantierul arheologic Porolissum. Materiale și Cercetări Arheologice 7: 361-390.

Macrea, M., Rusu, M. and Mitrofan, I. 1962. Șantierul Arheologic Porolissum. Materiale și Cercetări Arheologice 8: 484-504.

Mann, J., C. 1974. The frontiers of the Principate. Aufstieg und Niedergang der römischen Welt 2, 1: 508-533.

Marcu, F. and Cupcea, G. 2013. Topografia limes-ului de nord-vest al Daciei în zona castrului de la Bologa, in Stavilă, A., Micle, D., Cîntar, A., Floca, C. and Forțiu, S., (eds.), ArheoVest I: In memoriam Liviu Măruia. Interdisciplinaritate în arheologie și istorie: 569-589. Szeged: JATEPress Kiadó.

Marcu, F., Cupcea, G., Bajusz, M., Petiș, I., Cociș, H. and Zăgreanu, R. 2017. Frontiera Daciei Porolissensis între castrele de la Tihău și Cășeiu (Samum). Buletinul Limes 2: 20-24.

Marțian, I. 1920. Repertoriu arheologic pentru Ardeal. Bistrița: Muzeul de Istorie Bistrița.

Marțian, I. 1921. Urme din războaiele Romanilor cu Dacii. Cluj Napoca: .

Mason, R., A. and Croitoru, C. 2016. Carl Schuchhardt's Contributions on Ancient Linear Fortifications along the Lower Danube. Cluj-Napoca: Mega Publishing House.

Matei, Al. V. 1995. Șantierul arheologic Porolissum - Valul Dublu-Dealul Comorii, Cronica Cercetărilor Arheologice - Campania 1994. Bucharest: Ministry of Culture.

Matei, Al. V. 2005. Apeductele romane pe piloni de la Porolissum, Mușețeanu, C., V., Bărbulescu, M., Benea, D. (eds.). Corona Laurea. Studii în onoarea Luciei Țeposu Marinescu: 293-311. București: Editura Dacia.

Meyer, W., B. 2020. Enviromental Determinism, International Encycpedia of Human Geography: 175-181. Orlando (Florida, US): Elsevier. 
Moga, M. 1950. Traiul populației daco-romane și barbare la granița de vest a Daciei. Activitatea șantierului archeologic Porolissum. Studii și Cercetări de Istorie Veche 1: 131-135.

Mommsen, Th. 1885. Der Oberrheinische Limes. Westdeutsche Zeitschrift fur Geschichte und Kunst 4: 43-51.

Mommsen, Th. 1894. Der Begriff des Limes. Westdeutsche Zeitschrift fur Geschichte und Kunst 13: 43-51.

Mommsen, Th. 1908. Der Begriff des Limes. Gesammelte Schriften 5: 456-464.

Nedelea, L., Cociș, H. and Băcueț-Crișan, D. 2019. The Pottery Kilns from Porolissum-Sărata and the Problem of the Settlement's Inner Defensive Line. Acta Museii Porolissensis 41: 185-252.

Opreanu, C., H. 1994. Misiunile beneficiarilor consular pe limes-ul de nord al Daciei în secolul al III-lea d. Ch. Acta Museii Porolissensis 31: 69-80.

Ortvay, T. 1875. Dacia és Moesia terüléten. Archaeologiai Értesitó 9: 225-230.

Panaitescu, Em. 1929. Le limes dacique. Nouvelles fouilles et nouveaux résultats. Academia Română: 73-92.

Piganiol, A. 1963. La notion du limes, in Grga, N. (ed.). LIMES V. Quintus Congressus Internationalis Limitis Romanis Studiosorum:119-122. Zagreb : .

Piso, I. and Deac, D. 2016. Inscriptiones Daciae Romanae, Appendix I: Inscriptiones laterum Musei Zilahensis. Cluj-Napoca: Mega Publishing House.

Radnóti, A. 1945. A dáciai limes a Meszesen. Archaeologiai Értesitó 4-5 (1944-1945): 137-168.

Rómer, F., F. 1875. Újabb római feliratos kövek. Archaeologiai Értesitó 9: 247-249.

Rómer, F., F. 1876. Les Fossés du Diable en Hongrie, Rómer, F., F (ed.) Congrès international d'anthropologie et d'archéologie préhistoriques. Compte-rendu de la huitieme session a Budapest: 39-77. Budapest : Edition du Musée National Hongrois.

Rusu, M. 1974. Cetatea Moigrad și Porțile Meseșului în Sub semnlui lui Clio, Omagiu academicianului Ștefan Pascu, Cluj-Napoca: 265-279.

Symonds, M., F., A. 2018. Protecting the Roman Empire. Fortlets, Frontiers and the Quest for Post-Conquest Security. Cambridge: Cambridge University Press.

Székely Zs. 2010. Paul Reinecke și cercetarea limesului roman din Transilvania. Paul Reinecke and Roman Limes research from Transylvania, in Pop, H., Bejinariu, I., Băcueț-Crișan, S. and Băcueț-Crișan, D., (eds.), Identități culturale locale și regionale în context European. Studii de arheologie și antropologie istorică: $375-$ 382. Cluj - Napoca: Mega Publishing House.

Téglás G. 1907. A limes dacicus igazolása. Magyar Tudományos 18: 565-580.

Téglás G. 1909. Limesforschungen in Dakien. Klio 1: 262.

Torma, K. 1861. Tizenkét római felirat Daciából. Erdélyi Múzeum 1: 37-38.

Torma, K. 1863. Adalékok észak-nyugati Dacia föld-és helyiratához. Budapest: .

Torma, K. 1864. Az Alsó-Ilosvai római állótábor mủemlékei. Erdélyi Múzeum 3:10-67.

Torma K. 1880. A limes Dacicus felsö része. Budapest: .

Toth, E. 1978. Porolissum. Das Castellum in Moigrad. Ausgrabungen von A. Radnóti, 1943. Budapest: Magyar Nemzeti Múzeum.

Tudor, D. 1968. Orașe, târguri și sate in Dacia romană. București: Editura Științifică.

Vătavu, B.,-V. 2011. Regio și beneficiari consulari pe frontiera nordică a provinciei Dacia, in Pețan,A., Berzovan, Al., (eds.), Arheologie și Studii Clasice 1: 225-234. Cluj-Napoca: Editura Miracol.

Vincze, Z. 2000. Ferenczi István - régészsors Erdélyben (Ferenczi István - soartă de arheolog în Transilvania). Erdélyi Múzeu 62: 325-329.

Vincze, Z. 2000. Elfogult, emlékezés Ferenczi Istvánra (Evocare subiectivă a lui Ferenczi István). Müvelödés 53: 27-29.

Vincze, Z. 2001. In Memoriam István Ferenczi (1921-2000), Ephemeris Napocensis 11: 347-366.

Wagner, E. 1980. Preocupări de arheologie în Județul Sălaj oglindite în documente din anii 1870-1950. Acta Museii Porolissensis 4: 665-703.

Windisch, von K., G. 1790. Geographie des Königreichs Ungarn 3. Presburg: Anton Lowe.

Woolliscroft, D., J. 1994. Signalling and the design of the Gask Ridge System. Proceedings of the Society of Antiquaries of Scotland 123: 291-314. 
D. J. Woolliscroft. 2001. Roman Military Signalling. Stroud: Tempus.

D. J. Woolliscroft. 2010. Roman Military Signalling. Stroud: Tempus.

Zăgreau, R., Cociş, H., Gaiu, C., Vaida, D., L. and Bâcă, I. 2017. The Roman Frontier in Bistrița-Năsăud County. Part I. The Repertory. Journal of Ancient History and Archaeology 4/1: 25-45. DOI: 10.14795/j.v4i2.263

HORAȚIU COCIȘ

Zalău County Museum of History and Art hcocis12@gmail.com 


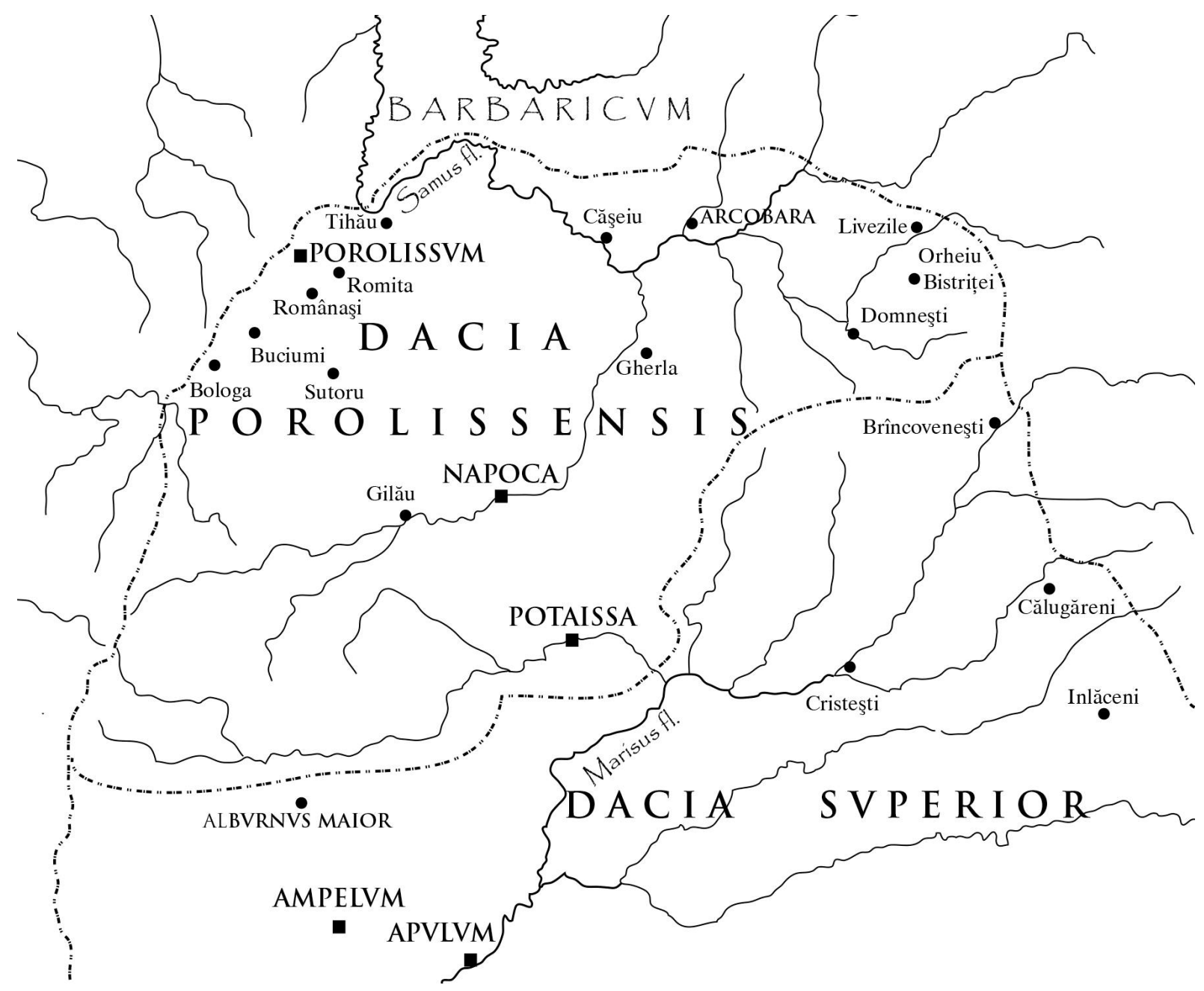

Pl. 1. Map of the frontier of Dacia Porolissensis (after Deac, Dana 2019, 114, Fig. 1). 


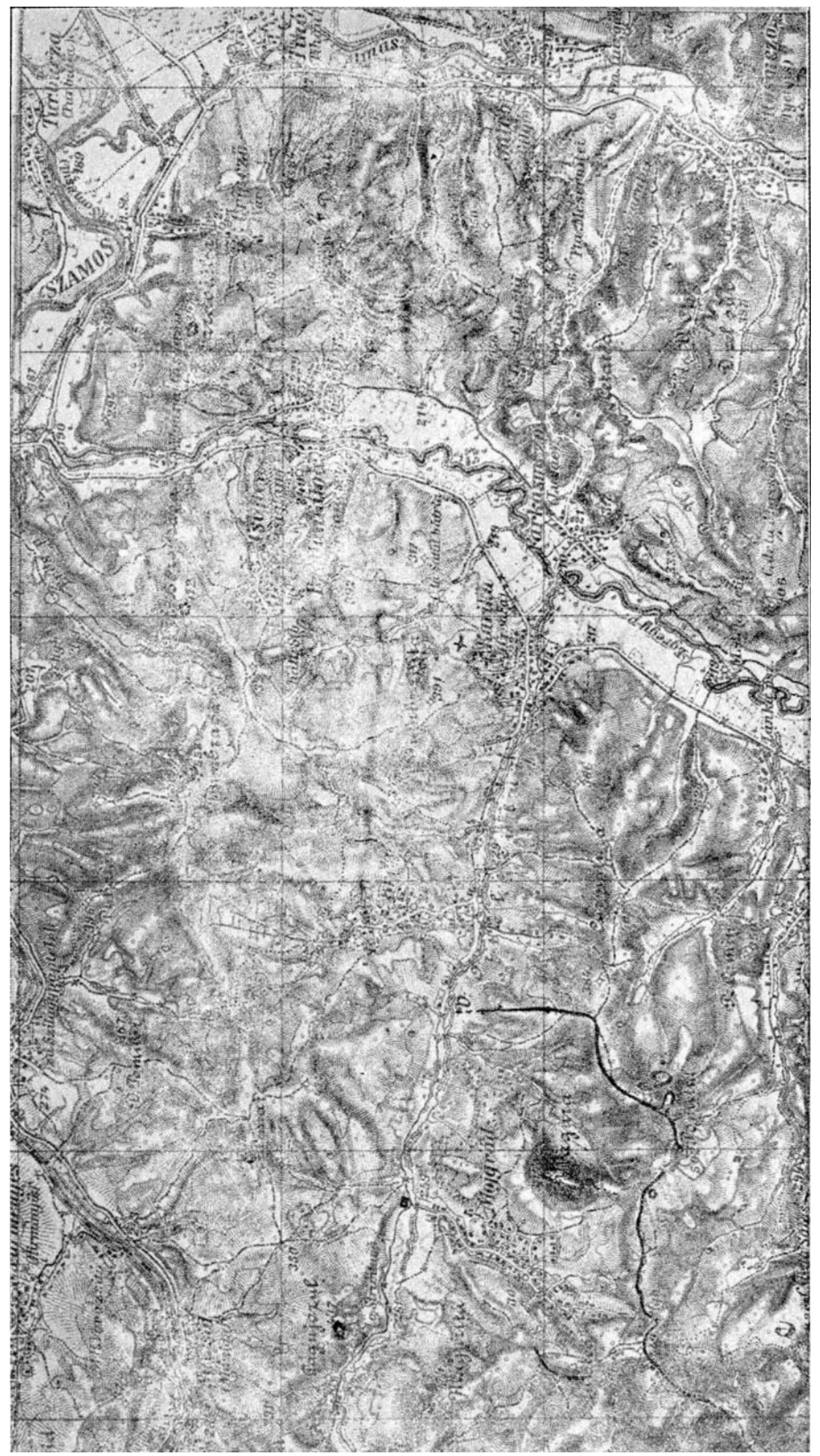

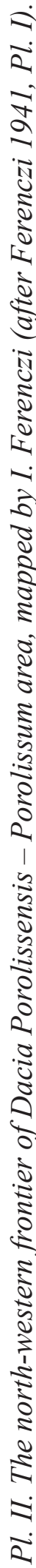




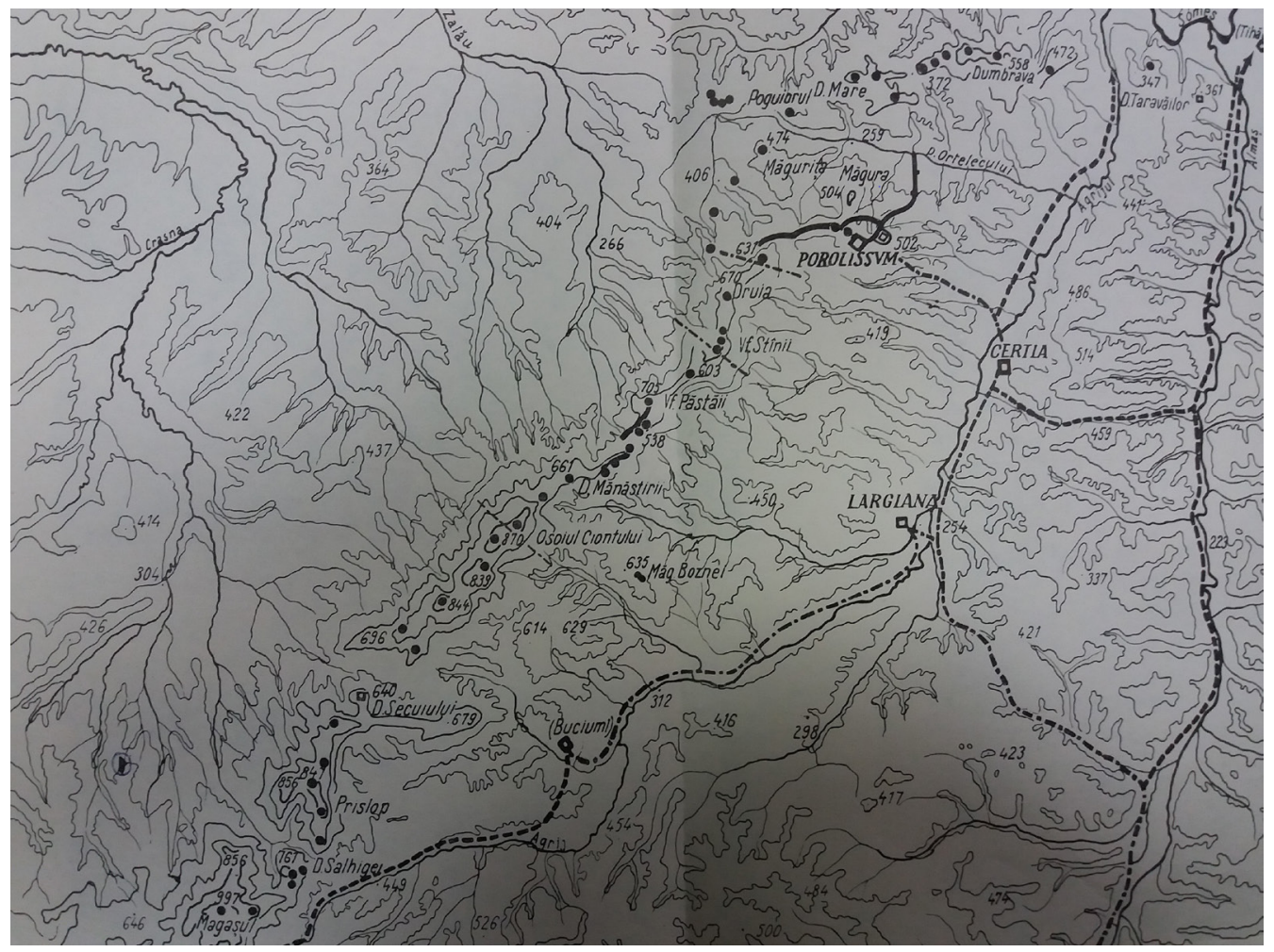

Pl. III. The north-western frontier of Dacia Porolissensis - the Meseș Mountains, mapped by I. (after Ferenczi 1967, Pl. I).

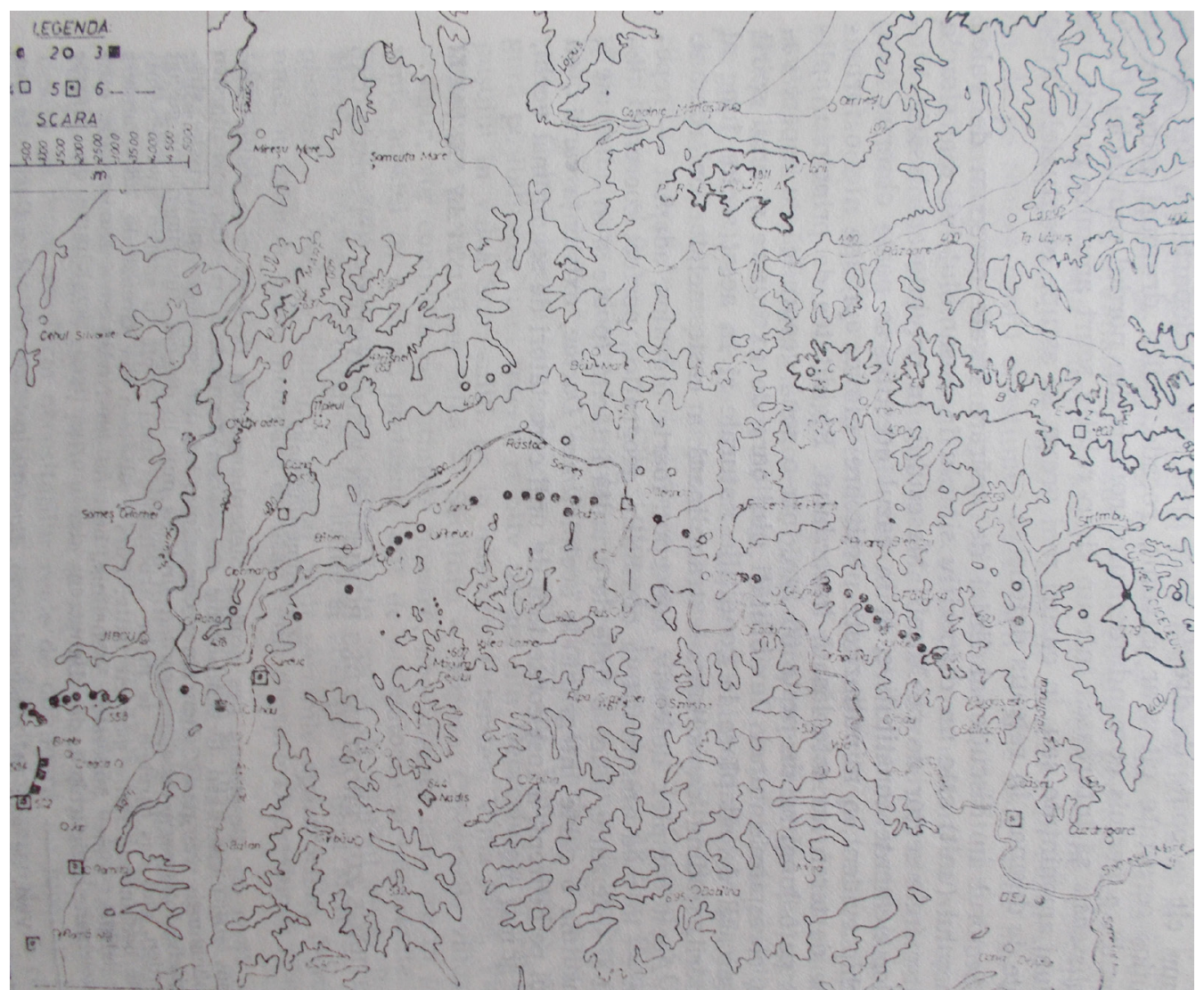

Pl. IV. The northern frontier of Dacia Porolissensis between the auxiliary forts at Tihău and Cășeiu, mapped by I. Ferenczi / Samum (after Ferenczi 1988, 187, Fig. 1). 


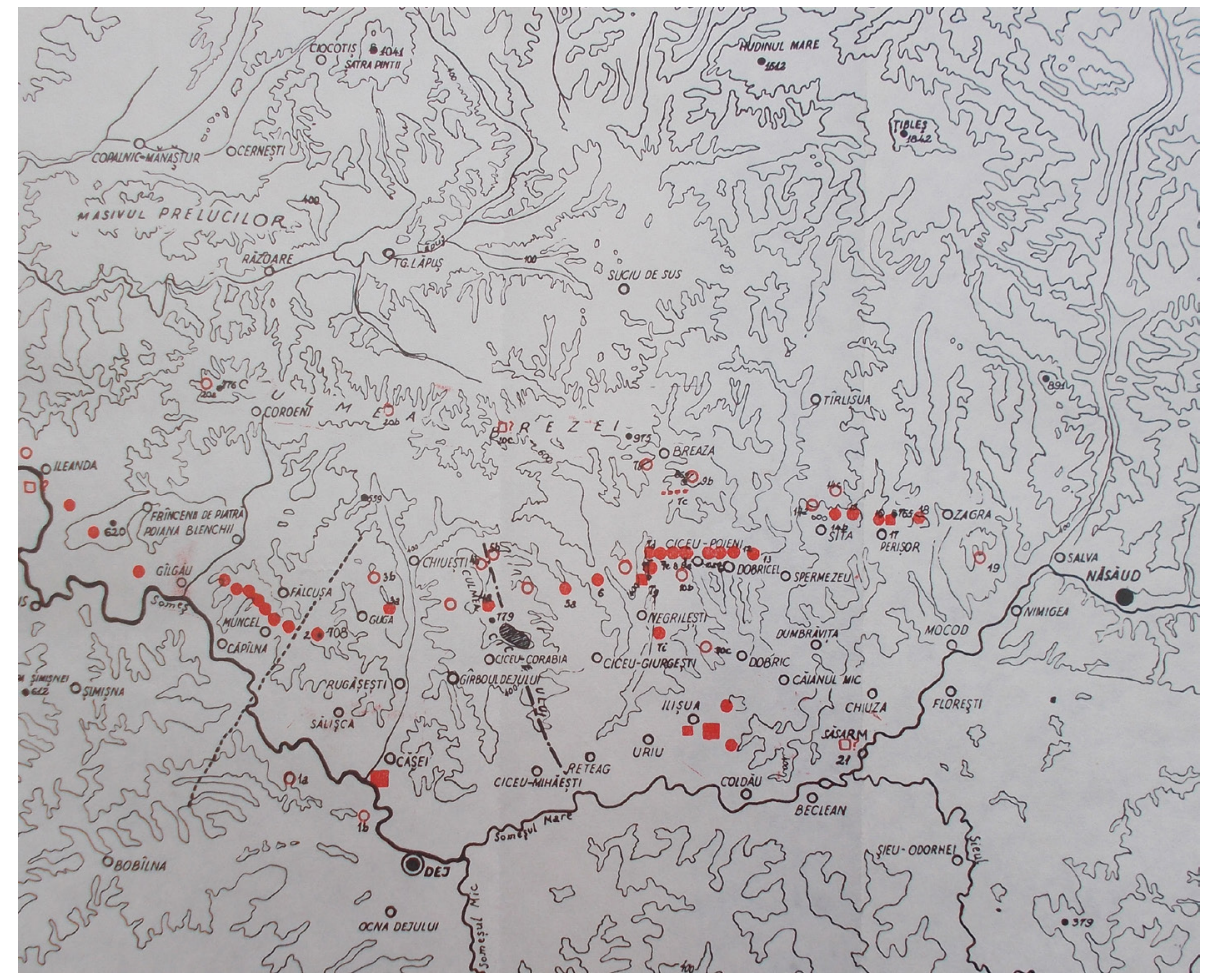

Pl. V. The northern

frontier of Dacia

Porolissensis between

Ileanda (Sălaj County)

and Salva (Bistrița-

Năsăud County), mapped

by I. Ferenczi (after

Ferenczi 1973, Pl. I).

Pl. VI. The north-

eastern frontier of Dacia Porolissensis between Zagra Valey and Mureș Valey, mapped by I. Ferenczi (after I. Ferenczi 1975, 289, Fig. 1).
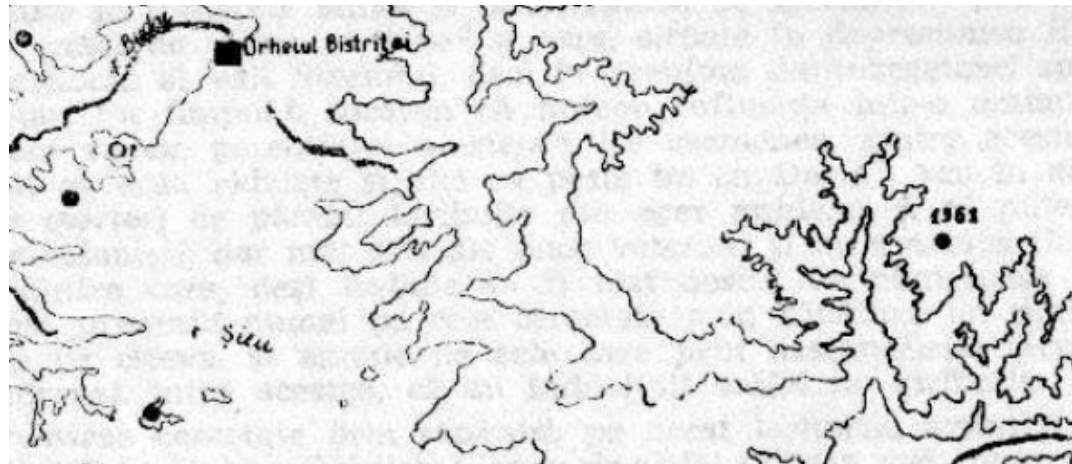

c

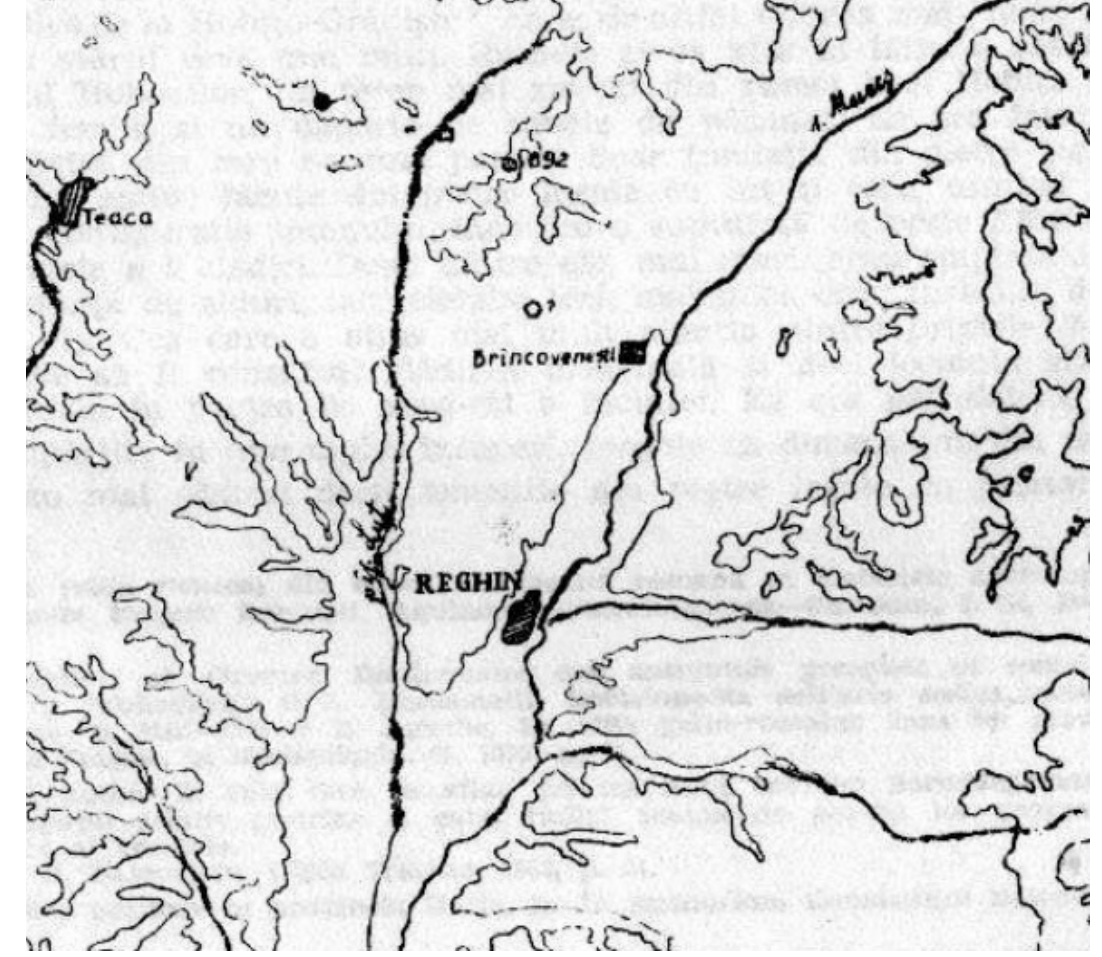


